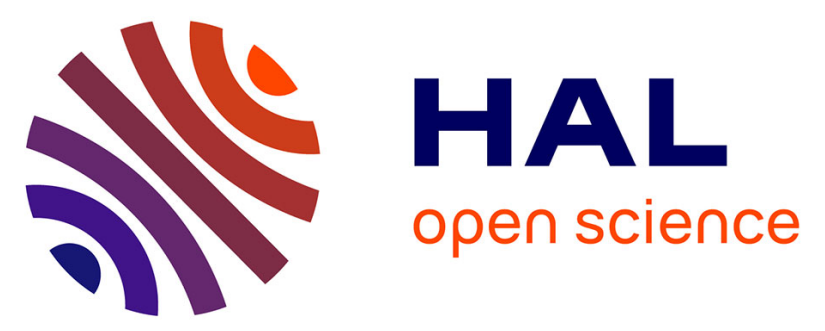

\title{
Interest of a multispecies approach in active biomonitoring: Application in the Meuse watershed
}

Audrey Catteau, Jean-Marc Porcher, Anne Bado-Nilles, Isabelle Bonnard,

Marc Bonnard, Arnaud Chaumot, Elise David, Odile Dedourge-Geffard, Laurence Delahaut, Nicolas Delorme, et al.

\section{To cite this version:}

Audrey Catteau, Jean-Marc Porcher, Anne Bado-Nilles, Isabelle Bonnard, Marc Bonnard, et al.. Interest of a multispecies approach in active biomonitoring: Application in the Meuse watershed. Science of the Total Environment, 2022, 808, pp.152148. 10.1016/j.scitotenv.2021.152148 . ineris03563548

HAL Id: ineris-03563548

https://hal-ineris.archives-ouvertes.fr/ineris-03563548

Submitted on 9 Feb 2022

HAL is a multi-disciplinary open access archive for the deposit and dissemination of scientific research documents, whether they are published or not. The documents may come from teaching and research institutions in France or abroad, or from public or private research centers.
L'archive ouverte pluridisciplinaire HAL, est destinée au dépôt et à la diffusion de documents scientifiques de niveau recherche, publiés ou non, émanant des établissements d'enseignement et de recherche français ou étrangers, des laboratoires publics ou privés. 


\section{Interest of a multispecies approach in active biomonitoring: application in the Meuse watershed.}

$\underline{\text { Audrey Catteau }}^{1^{\star}}$, Jean-Marc Porcher ${ }^{2}$, Anne Bado-Nilles ${ }^{2}$, Isabelle Bonnard', Marc Bonnard", Arnaud Chaumot $^{3}$, Elise David ${ }^{1}$, Odile Dedourge-Geffard ${ }^{1}$, Laurence Delahaut ${ }^{1}$, Nicolas Delorme $^{3}$, Adeline François ${ }^{3}$, Laura Garnero ${ }^{3}$, Christelle Lopes ${ }^{4}$, Katherine Nott ${ }^{6}$, Patrice Noury ${ }^{3}$, Olivier Palluel ${ }^{2}$, Mélissa Palos-Ladeiro ${ }^{1}$, Hervé Quéau ${ }^{3}$, Sébastien Ronkart ${ }^{6}$, Khadija SosseyAlaoui $^{5}$, Cyril Turiès ${ }^{2}$, Bernard Tychon ${ }^{5}$, Olivier Geffard ${ }^{3}$, Alain Geffard $^{1^{*}}$

${ }^{1}$ Université de Reims Champagne-Ardenne (URCA), UMR-I 02 SEBIO, UFR Sciences Exactes et Naturelles, Campus Moulin de la Housse, BP 1039, 51687 Reims, France.

${ }^{2}$ Institut National de l'Environnement et des Risques (INERIS), UMR-I 02 SEBIO (Stress Environnementaux et Biosurveillance des milieux aquatiques), BP 2, 60550 Verneuil-en-Halatte, France.

${ }^{3}$ INRAE, UR RiverLy, Laboratoire d'écotoxicologie, F-69625 Villeurbanne, France

${ }^{4}$ Université de Lyon 1, CNRS, Laboratoire de Biométrie et Biologie Evolutive, UMR 5558, Villeurbanne, 69622, France

${ }^{5}$ Département des Sciences et Gestion de L'environnement (Arlon Campus Environnement), Eau, Environnement, Développement Sphères Bât. BE-009 Eau, Environnement, Développement, Avenue de Longwy 185, 6700 Arlon, Belgium

${ }^{6}$ La société wallonne des eaux, rue de la Concorde 41, 4800 Verviers, Belgium

"Corresponding authors:

audrey.catteau@univ-reims.fr

alain.geffard@univ-reims.fr 


\section{GRAPHICAL ABSTRACT}

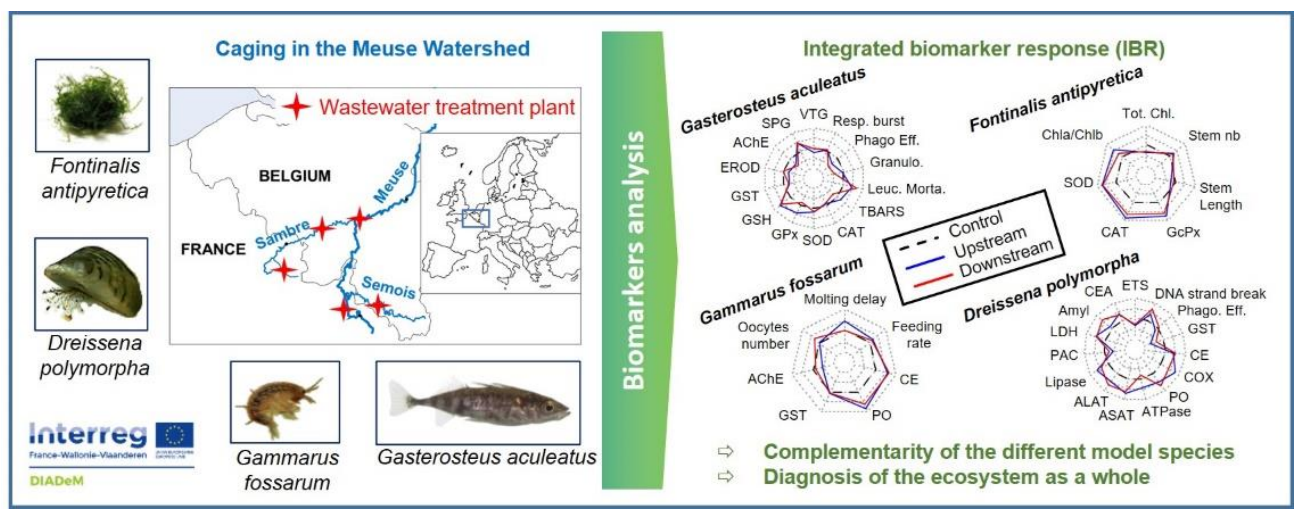

\section{ABSTRACT}

A biomonitoring approach based on a single model species cannot be representative of the contaminations impacts on the ecosystem overall. As part of the Interreg DIADeM program (« Development of an integrated approach for the diagnosis of the water quality of the River Meuse »), a study was conducted to establish the proof of concept that the use of a multispecies active biomonitoring approach improves diagnostic of aquatic systems. The complementarity of the biomarker responses was tested in four model species belonging to various ecological compartments: the bryophyte Fontinalis antipyretica, the bivalve Dreissena polymorpha, the amphipod Gammarus fossarum and the fish Gasterosteus aculeatus. The species have been caged upstream and downstream from five wastewater treatment plants (WWTPs) in the Meuse watershed. After the exposure, a battery of biomarkers was measured and results were compiled in an Integrated Biomarker Response (IBR) for each species. A multispecies IBR value was then proposed to assess the quality of the receiving environment upstream the WWTPs.

The effluent toxicity was variable according to the caged species and the WWTP. However, the calculated IBR were high for all species and upstream sites, suggesting that the water quality was already downgraded upstream the WWTP. This contamination of the receiving environment was confirmed by the multispecies IBR which has allowed to rank the rivers from the less to the most contaminated. This study has demonstrated the interest of the IBR in the assessment of biological impacts of a point-source contamination (WWTP effluent) but also of the receiving environment, thanks to the use of independent references. Moreover, this study has highlighted the complementarity between the different species and has emphasized the interest of this multispecies approach to consider the variability of the species exposition pathway and sensibility as well as the mechanism of contaminants toxicity in the final diagnosis. 


\section{KEYWORDS}

Integrated biomarker response, Wastewater treatment plant, Amphipod, Fish, Bivalve, Bryophyte

\section{HIGHLIGHTS}

- An active biomonitoring approach was performed in the Meuse watershed with four different model species

- The wide use range of the four model species have been highlighted

- IBR is a good way to rapidly compare biomarker responses of different species

- The final diagnosis can vary according to the model species

- The complementarity of the different species belonging to various ecological compartments was demonstrated 


\section{INTRODUCTION}

The most part of rivers in industrial countries, is subjected to a chemical pressure from multiple sources (agricultural, industrial and urban). The presence of micropollutants (i.e. pharmaceuticals, personal care products, hormones, pesticides, industrial chemicals) has become a widespread problem. These molecules are mainly introduced into aquatic environments by point sources like wastewater treatment plants (WWTPs) effluents. In fact, the treatments implemented within the WWTPs do not completely eliminate some of these persistent molecules. They are released in the effluents and are widely found at concentrations of the order of a few nanograms or micrograms per liter in surface water (Blum et al., 2018; Metcalfe et al., 2014).

To assess the effect of contamination induced by WWTPs on living organisms, the subindividual biomarkers, studied for about thirty years, appear to be valuable tools. They are defined as "change in biological response (ranging from molecular through cellular and physiological responses to behavioural changes) which can be related to the exposure of a sentinel organism to some chemicals or to the toxicant effect of these chemicals" (Peakall and Walker, 1994). Biomarkers can be applied in passive biomonitoring approach, involving measuring the biomarkers on indigenous individuals from the sites studied, or in active biomonitoring approach, using transplanted (or caged) organisms coming from a reference site or a laboratory breeding. The second one presents numerous advantages. This approach is not dependant on the model species and makes it possible to study any site of interest regardless of the presence or absence of the species. Also, some confounding factors can be controlled (size, sex, age of the sampled individuals, exposure time and area) limiting the variability of measurements and facilitating the interpretation of the data (Coulaud et al., 2011; Lopes et al., 2020; Marchand et al., 2019). In addition, mechanisms of acclimatization or adaptation to chronic contamination may appear in native populations, which can lead to modulate biomarkers levels. Finally, the passive approach on species as fish questions the characterization of their exposure to studied point-source contamination (possibility to avoid contamination). Despite some inconvenient that can be mentioned (stress of organism's transport on a study site, possible restriction of food access), the actives approaches seem now to appear as the most promising strategy to process biomonitoring studies.

As a single biological parameter is not representative of the individual's state of health, a combination of multiple biomarkers can be measured in each model species to achieve an integrated assessment of the toxicity of contamination (Galloway et al., 2004). The assessment of a large number of biological parameters generates large datasets which can be integrated into multi-biomarker indices to facilitate the interpretation of results. Among existing indices (i.e. Health Assessment Index, Bioeffect Assessment Index, Multimarker pollution index, Health Statut Index, Biomarker Response Index...) (Aarab et al., 2004; Adams et al., 1993; Broeg et al., 2005; Dagnino et al., 2007; Hagger et al., 2008), the most used is the "Integrated Biomarker Response " (IBR), initially developed by Beliaeff_and Burgeot (2002). The whole biomarker data are represented on a single radar plot (one biomarker per branch). The area of the geometric shape created constitutes the final IBR score of the studied site. 
More recently, Sanchez et_al._(2013) have proposed a modified IBR (IBRv2) which is based on the difference between the biomarker responses measured and reference values. The reference can be the biomarkers levels in a site without chemical contamination or in individuals sampled in the original population (active approaches). This IBRv2 has been successfully used in one-single test species studies, both in field (Cao et al., 2018; Catteau et al., 2020; Sanchez et al., 2013) and laboratory studies (Sobjak et al., 2017).

Several aquatic organisms (fish, bivalves, crustaceans, plants) can be used in biomonitoring. The most part of biomonitoring studies found in literature used only one model species (Besse et al., 2013; Catteau et al., 2020; Dazy et al., 2009; Gouveia et al., 2017; Hani et al., 2021; Palais et al., 2012). However, a single species cannot be representative of the contaminations impacts on the ecosystem overall. The biological and physiological differences between phylogenetically and ecologically distant organisms as well as the difference in contamination pathways are all factors that can influence the contamination impacts and thus the biomarker responses of the chosen model species.

To develop cross-border approaches for assessing the water quality of the Meuse watershed, the European Interreg DIADeM program ("Development of an Integrated Approach for the Diagnosis of the water quality of the Meuse River") was created. One objective of the DIADeM program was to assess the effects of contamination induced by WWTPs on living organisms in the Meuse, its tributaries and sub-tributaries. This watershed undergoes indeed significant agricultural and industrial pressures but also an important contamination with emerging micropollutants (International Meuse Commission, 2005). The originality of this research program rests on the use of several model species in an active biomonitoring approach to ensure complementarity in the exposure pathways. Four model species were selected among species currently used in active biomonitoring: i) a bryophyte (Fontinalis antipyretica Hedw.) as primary producer, ii) a crustacean (Gammarus fossarum) and iii) a bivalve (Dreissena polymorpha) as primary consumers, respectively detritivores and filter feeders, and iv) a fish (Gasterosteus aculeatus) as a secondary carnivorous consumer. The four selected species belong to various ecological compartments and trophic levels (primary producer, filter feeder, detritivore and predator) and are representative of an ecosystem as a whole. All these species are considered as good biological models because of their very wide geographic distribution and their tolerance to pollution. More specifically, the zebra mussel $D$. polymorpha is a bivalve with bioecological traits which make it particularly relevant in biomonitoring. This sedentary mussel is commonly found in a wide habitat diversity in Europe and North America (de Lafontaine et al., 2000). Moreover, this mussel presents a high filtration rate and high bioaccumulation potential which make it an extensively used indicator for filed biomonitoring studies and laboratory experiments (Evariste et al., 2018; Kerambrun et al., 2016a, 2016b). Similarly, the amphipod G. fossarum is an amphipod very widespread in the Western Europe rivers and is also regularly used in many active biomonitoring studies (Besse et al., 2013; Dedourge-Geffard et al., 2009; Lacaze et al., 2011). This model is ecologically relevant because the Gammarus spp. constitute an important reserve of food for many species (fish, birds, amphibians) (Friberg et al., 1994; Macneil et al., 1997; Welton, 1979) and play a major role in the leaf-litter degradation processes (Maltby et al., 2002). The caging technique is fine mastered with these two species. The frequent use of $G$. fossarum in active biomonitoring studies 
have led to create a well-defined protocol which was recently normalised in France (AFNOR XP T90722-2). Representative of the fish compartment, the three-spined stickleback G. aculeatus is a relatively ubiquitous species found in many temperate zones of the northern hemisphere. This euryhaline species was found to be resistant to pollution and easy to handle and maintain in breeding. This species is thus increasingly used in active biomonitoring studies (Catteau et al., 2021, 2020; Le Guernic et al., 2016) and emerged as a new species of interest. Finally, the bryophyte $F$. antipyretica is the most widely used aquatic plant for biomonitoring. Although it is mainly used as bioaccumulator of metals (Bruns et al., 1997; Mersch and Pihan, 1993; Siebert et al., 1996), PAHs (Polycyclic Aromatic Hydrocarbons) and persistent pollutants (Augusto et al., 2013, 2011), the use of biomarkers has been proven in this species, especially those associated with the oxidative stress (Dazy et al., 2009) and the photosynthesis (Bruns et al., 1997; Yurukova and Gecheva, 2003).

The aim of this work is to highlight the complementarity of the different model species from various trophic levels in biomonitoring within the framework of DIADeM program. The biomarker responses are compared between the four selected species thanks to IBRv2 calculations. The interest of this work lies in the use of integrated indexes based on a multispecies and multibiomarkers approach to establish a global diagnosis comparable between stations. This study can be considered as a proof of concept of using a multispecies active approach to assess water quality. 


\section{MATERIAL AND METHODS}

\subsection{Description of the study sites}

Five WWTPs were studied along the Meuse watershed. The largest is the WWTP of Charleroi (50²4'12.827"N 4²7'31.659"E, Belgium), which has a capacity of 200000 population-equivalent (PE) with an average incoming flow of $31087 \mathrm{~m}^{3} /$ day. The effluent from this WWTP flows into the Sambre, one of the most important tributaries of the Meuse with an average flow of $36 \mathrm{~m}^{3} / \mathrm{s}$ and whose confluence is located a few kilometers upstream from the city of Namur. The second WWTP is located in Charleville-Mézières (49 45'55.3"N 443'43.5"E, France) and has a capacity of 117000 PE for an average incoming flow of $12278 \mathrm{~m}^{3} /$ day. Its effluent flows directly into the Meuse (average flow of 230 $\left.\mathrm{m}^{3} / \mathrm{s}\right)$. The wastewater treatment plant in Namur $\left(50^{\circ} 28^{\prime} 51.2^{\prime \prime} \mathrm{N} 4^{\circ} 57^{\prime} 18.1^{\prime \prime} \mathrm{E}\right.$, Belgium) was also investigated. This WWTP has a dimensional capacity of 93100 PE for an average incoming flow of 20 $600 \mathrm{~m}^{3} /$ day. Its effluent flows into the Meuse, $80 \mathrm{~km}$ downstream from Charleville-Mézières and downstream from the confluence with the Sambre. In addition, two little WWTPs flowing in Meuse tributaries were investigated. The WWTP of Avesnes-sur-Helpe (19 830 PE, $50^{\circ} 07^{\prime} 48.5^{\prime \prime} \mathrm{N}$ $3^{\circ} 55^{\prime} 13.6 " E$, France) flows in the river Helpe Majeure (average flow of $3.86 \mathrm{~m}^{3} / \mathrm{s}$ ) and the WWTP of Bouillon (7500 PE, 49 47'24.0"N 503'00.0"E, Belgium) flows in the river Semois (average flow of 26 $\mathrm{m}^{3} / \mathrm{s}$ ) (Fig. 1). All of the studied WWTPs use activated sludge treatment. The WWTPs in Charleroi and Namur have also specific nitrogen and phosphorus treatment (chemical and biological). The WWTP of Bouillon is located in an area with great tourist activity and is therefore endowed with tertiary UV treatment.

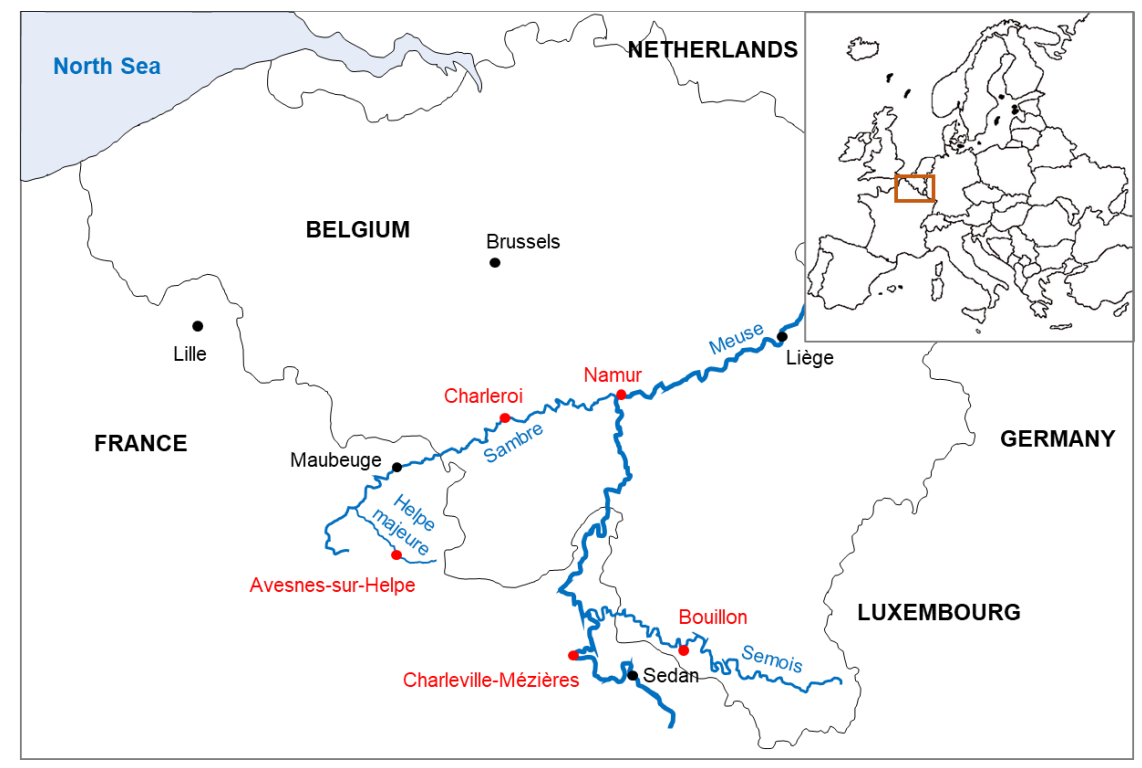

Fig. 1: Localisation of studied sites in France and Belgium along the

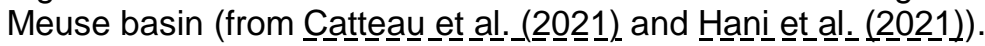

During the study, several water samples were taken upstream and downstream from the WWTP effluents to carry out chemical analyses. Results for the 45 compounds monitored are available in Catteau et al. (2021) and Hani et al. (2021). These data were used to summarize the global 
contamination by pharmaceuticals and domestic tracers in each site (Table 1). Data clearly demonstrate the involvement of the WWTPs effluents in the increasing downstream contamination in Bouillon, Namur and Charleroi. On the contrary, the effluent of Charleville-Mézières induces a slight increase in contamination and no increase contamination was observed for the effluent of Avesnessur-Helpe WWTP. In addition to the contaminants brought by the effluents, the rivers present differences in chemicals level even upstream the WWTP. The chemical contamination in the Semois, the Helpe-Majeure and the Meuse at Charleville-Mézières appear to be lower than in the Meuse at Namur and the Sambre.

Table 1: Summary of pharmaceuticals and domestic tracers contamination in each site. For the pharmaceuticals, the mean was calculated from the concentrations measured for the 45 compounds monitored. For domestic activity tracers, the mean of the concentrations measured for caffeine and cotinine was calculated (modified from Catteau et al. (2021)).

\begin{tabular}{|c|c|c|c|c|c|c|}
\hline \multirow{2}{*}{ Municipality } & \multirow{2}{*}{ River } & \multirow{2}{*}{$\begin{array}{l}\text { Localisation } \\
\text { (from the WWTP) }\end{array}$} & \multicolumn{2}{|c|}{ Pharmaceuticals } & \multicolumn{2}{|c|}{ Domestic activity tracers } \\
\hline & & & Mean (ng/L) & CV (\%) & Mean (ng/L) & CV (\%) \\
\hline \multirow{2}{*}{$\begin{array}{l}\text { Avesne-sur- } \\
\text { Helpe }\end{array}$} & \multirow{2}{*}{$\begin{array}{l}\text { The Helpe- } \\
\text { Majeure }\end{array}$} & Upstream & 440 & 19 & 171 & 62 \\
\hline & & Downstream & 426 & 13 & 167 & 63 \\
\hline \multirow{2}{*}{ Bouillon } & \multirow{2}{*}{ The Semois } & Upstream & 389 & 57 & 100 & 15 \\
\hline & & Downstream & 1629 & 96 & 170 & 33 \\
\hline \multirow{2}{*}{ Charleroi } & \multirow{2}{*}{ The Sambre } & Upstream & 2489 & 13 & 905 & 59 \\
\hline & & Downstream & 4123 & 22 & 1725 & 64 \\
\hline \multirow{2}{*}{$\begin{array}{l}\text { Charleville- } \\
\text { Mézières }\end{array}$} & \multirow{2}{*}{ The Meuse $\mathrm{P}^{(1)}$} & Upstream & 535 & 48 & 172 & 40 \\
\hline & & Downstream & 732 & 24 & 164 & 41 \\
\hline \multirow{2}{*}{ Namur } & \multirow{2}{*}{ The Meuse $^{(2)}$} & Upstream & 2041 & 111 & 637 & 63 \\
\hline & & Downstream & 4337 & 47 & 614 & 62 \\
\hline
\end{tabular}

The water temperature was recorded throughout the experiment thanks to temperatures loggers. The conductivity and the $\mathrm{pH}$ were measured at the beginning and the end of the exposure. These physicochemical parameters are indicated in Table 2. Few differences can be observed between upstream and downstream of the different sites, except for Charleroi where the conductivity increases strongly downstream of the effluent.

Table 2: Physicochemical parameters of studied sites. Results are expressed with arithmetical mean \pm standard deviation.

\begin{tabular}{|c|c|c|c|c|c|c|c|c|c|c|}
\hline & & \multicolumn{3}{|c|}{$\begin{array}{c}\text { Temperature } \\
\left({ }^{\circ} \mathrm{C}\right)\end{array}$} & \multicolumn{3}{|c|}{ Conductivity $(\mu \mathrm{S} / \mathrm{cm})$} & \multicolumn{3}{|c|}{$\mathrm{pH}$} \\
\hline & & Mean & \pm & Sd & Mean & \pm & Sd & Mean & \pm & Sd \\
\hline \multirow{2}{*}{$\begin{array}{c}\text { Avesnes-sur- } \\
\text { Helpe }\end{array}$} & Upstream & 12.5 & \pm & 1.5 & 505.8 & \pm & 122.2 & 8.0 & \pm & 0.4 \\
\hline & Downstream & 12.6 & \pm & 1.5 & 379.0 & \pm & 20.5 & 7.9 & \pm & 0.2 \\
\hline \multirow{2}{*}{ Bouillon } & Upstream & 13.1 & \pm & 1.7 & 310.0 & \pm & 26.4 & 8.6 & \pm & 0.5 \\
\hline & Downstream & 13.4 & \pm & 1.6 & 314.0 & \pm & 26.7 & 8.6 & \pm & 0.3 \\
\hline \multirow{2}{*}{ Namur } & Upstream & 12.3 & \pm & 3.3 & 741.3 & \pm & 146.7 & 8.2 & \pm & 0.1 \\
\hline & Downstream & 12.5 & \pm & 3.2 & 763.3 & \pm & 140.6 & 8.1 & \pm & 0.1 \\
\hline
\end{tabular}




\begin{tabular}{cccccccccc}
$\begin{array}{c}\text { Charleville- } \\
\text { Mézières }\end{array}$ & Upstream & 10.6 & \pm 3.0 & 596.8 & \pm 12.7 & 8.2 & \pm 0.1 \\
& Downstream & 10.8 & \pm 3.0 & 598.0 & \pm 12.8 & 8.2 & \pm & 0.1 \\
\hline \multirow{2}{*}{ Charleroi } & Upstream & 11.4 & \pm 3.2 & 672.5 & \pm 16.3 & 8.1 & \pm & 0.2 \\
& Downstream & 11.9 & \pm & & \pm .1 & 1024.5 & \pm 172.1 & 8.0 & \pm \\
\hline
\end{tabular}

\subsection{Experimental design}

The caging was carried out in autumn, between September and December 2018. Autumn corresponds to the sexual rest period of $G$. aculeatus and $D$. polymorpha and therefore constitutes an appropriate season for the use of these models in biomonitoring to limit the variability linked to reproduction (Catteau et al., 2019; Palais et al., 2012). As far as practicable, all species have been caged in all sites studied. However, the invasive nature of $D$. polymorpha limited its use on stations where native populations are present (Namur, Charleville-Mézières and Charleroi). In addition, for practical reasons, G. aculeatus and F. antipyretica could not be caged at the Charleroi sites. All species were caged in the same period (between the $24^{\text {th }}$ of September and the $26^{\text {th }}$ of November 2018) for 3 weeks (G. aculeatus, F. antipyretica, G. fossarum) or 2 months (D. polymorpha). The precise dates of cage installations and individuals recovery are indicated in Table S1.

The three-spined sticklebacks $G$. aculeatus used in this study came from the breeding facilities of the French National Institute for Industrial Environment and Risks (INERIS, 49¹6'21.0"N 2³0'12.7"E). They were sexed (De Kermoysan et al., 2013) and maintained separated by gender in outdoor ponds chemical contamination free under ecosystem conditions (outside ponds with continuous renewal of water, natural vegetation and macroinvertebrate communities) until the field experiment. In September 2018, adult three-spined sticklebacks (1-year-old; $4.40 \pm 0.45 \mathrm{~cm} ; 1.07 \pm 0.34 \mathrm{~g}$ ) were caged upstream ( 2 cages) and downstream (2 cages) from the WWTPs at a rate of 30 fishes in each studied site ( 15 fish / cages) during 21 days. Cages used were cylindrical stainless steel tanks of $630 \mathrm{~mm}$ high, $270 \mathrm{~mm}$ diameter (volume $=36 \mathrm{~L}$ ) and $5 \mathrm{~mm}$ mesh (Catteau et al., 2021).

The zebra mussels $D$. polymorpha ( $2 \pm 0.1 \mathrm{~cm}$ shell length) were collected in October 2018 from the "Lac du Der-Chantecoq" (northeastern France, 48 ${ }^{\circ} 35^{\prime} 02.3^{\prime \prime} \mathrm{N} 4^{\circ} 43^{\prime} 27.9^{\prime \prime} \mathrm{E}$ ) considered as a reference site. After a two-weeks acclimation period in aerated laboratory tanks at $14^{\circ} \mathrm{C}$ in darkness, mussels were randomly placed in 2-mm-mesh polyethylene cages $(7 \times 7 \times 14 \mathrm{~cm})(200$ mussels per cage). The cages were then installed for two months upstream ( 1 cage) and downstream (1 cage) from the WWTPs (Hani et al., 2021).

Adults G. fossarum were collected, through 2- and 2.5- $\mathrm{mm}$ sieves, on a bygone watercress farm located in Saint-Maurice-de-Remens (eastern central France), acclimatized to laboratory conditions and caged in field as previously described (Jubeaux et al., 2012). Organisms were collected by kick sampling using a net, and quickly transported to the laboratory. They were then kept in tanks continuously supplied with drilled groundwater and under aeration for at least 10 days before being used. A 16/8h light/dark photoperiod was maintained, the temperature was kept at $12 \pm 1{ }^{\circ} \mathrm{C}$ and organisms were fed ad libitum with alder leaves (Alnus glutinosa). Male organisms and AB-moulting 
stage females were caged and fed ad libitum with alder leaves during exposure. They were placed in punctured polypropylene cylinders to allow free circulation of water. Polypropylene cylinders, containing 20 males (plus 20 alder leaves discs of known diameters for feeding rate assessment) or 10 females are placed on each studied site for 7 and 21 days respectively, according to the biological responses studied.

Bryophytes F. antipyretica (branched clumps of 40 to $50 \mathrm{~cm}$ ) were collected at October 2018 in the reference water bodies defined in Wallonia for the sub-basins of the Semois-Chiers (Meuse watershed) (Galoux et al., 2015; Sossey-Alaoui and Rosillo, 2013). After collecting, the mosses were further acclimatized in river water for 2 weeks under laboratory conditions (16:8 h light/dark cycle at 15 $\pm 2 \mathrm{C}$, with constant aeration). Mosses were then placed in nylon cages $\left(15 \times 20 \mathrm{~cm}, 6-30 \mathrm{~mm}^{2}\right.$ mesh size) (200 g per cage). The cages were then installed for one month upstream ( 3 cages) and downstream ( 3 cages) from the WWTPs.

\subsection{Biomarker analysis}

\subsubsection{Gasterosteus aculeatus}

At the end of exposure, the three-spined stickleback were anesthetized by balneation in MS222 (Tricaine methanesulfonate, $100 \mathrm{mg} / \mathrm{L}$, Sigma-Aldrich, USA) and were sacrified by cervical dislocation. This experiment was conducted in accordance with the European directive 2010/63/UE on the protection of animals used for scientific purposes at INERIS facilities (registration number E60-76902).

The protocols for biological samples recovery and biomarker analysis in the three-spined stickleback

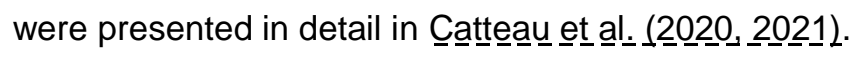

Briefly, blood samples $(5 \mu \mathrm{L})$, kidneys, livers and pieces of muscle were recovered and placed in the appropriate buffer solutions. The spleen was also recovered and smashed through sterilized nylon mesh (40 $\mu \mathrm{m}$, Sigma-Aldrich, USA) with Leibovitch medium (L15, Sigma-Aldrich, USA) modified by adding penicillin (500 mg/L, Sigma-Aldrich, USA) and streptomycin (500 mg/L, Sigma-Aldrich, USA), as described in the previous cited studies. The blood and organ samples were stored at $-80^{\circ} \mathrm{C}$ before biomarkers analysis and the leucocyte suspension from the spleen was stored at $4^{\circ} \mathrm{C}$ for 18 hours before analysis.

All biomarker analyses were performed on individual fish and are described in previous cited studies (Catteau et al., 2021, 2020).

Briefly, the leucocyte suspensions were used to assess some innate immune parameters, such as the cellular mortality percentage (apoptosis and necrosis), the leucocyte distribution (percentage of granulocytes and lymphocytes among leucocytes), the phagocytosis efficiency and the respiratory burst capacity. Analyses were carried out using flow cytometer (MACSQuant X, Miltenyi Biotec, USA)

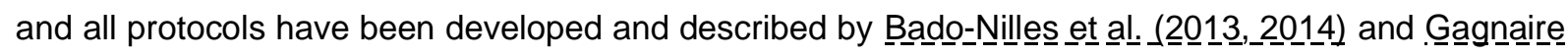
et_al. $(2015)$. 
Muscles and livers were grinded with glass beads (diameter of $1 \mathrm{~mm}$ ) and centrifuged $(10,000 \mathrm{~g}, 15$ $\min , 4^{\circ} \mathrm{C}$ ) for recovering the supernatant (post-mitochondrial fraction S9). Muscles supernatants were used to assess the acetylcholinesterase activity (AChE). Livers supernatants were used to assess the total glutathione concentration (GSH), the superoxide dismutase activity (SOD), the glutathione peroxidase activity (GPx), the catalase activity (CAT) and the thiobarbituric reactive substance concentration (TBARS), as biomarkers of oxidative stress. Two enzymes involved in metabolisation detoxication were also analysed, namely the ethoxyresorufin-O-deethylase activity (EROD) and the glutathione-S-transferase activity (GST). All these biomarkers were expressed according to the protein concentration, measured using the Bradford method (Bradford (1976).

The vitellogenin concentration (VTG) was measured in the blood samples of male sticklebacks and the spiggin concentration (SPG) were measured in the kidneys of female sticklebacks. Theses biomarkers are representative of potential endocrine disruption and were assessed through ELISA tests.

All these biochemical biomarkers (oxidative stress, detoxification enzymes and endocrine perturbation) were adapted on three-spined sticklebacks by Sanchenez et al al. $(20005,2007,20006)$.

\subsubsection{Gammarus fossarum}

At the end of exposure, organisms were counted (for survival rate assessment) and directly used to measure reproductive markers in females (moulting stages and fecundity) or weighed, frozen in liquid nitrogen and stored at $-80{ }^{\circ} \mathrm{C}$ for measurement of molecular biomarkers in males. Remains of alder leaves placed with males are also collected for the measurement of the feeding rate.

\section{Reproductive capacity}

The molt stage (molting delay) and the number of oocytes per female were evaluated as described by Geffard et al al. (2010). according to the French standard protocol AFNOR XP T90-722-2. Molt stage of females was identified by the integumental morphogenesis observation of the third and fourth periopod pairs in optical microscopy (x 200). The number of oocytes per female (fecundity) was counted by in vivo observations of the gonads under binocular microscope and standardized by dividing the total count of oocytes by female body-size.

\section{Feeding assay}

The feeding rate was assessed according to the procedure described in Coulaud__et__al._(2011) according to the French standard protocol AFNOR XP T90-722-3. As previously presented, 20 male gammarids and 20 leaf discs (20 mm diameter) were enclosed in perforated cylinders (four replicates per site). After 7 days, leaf discs were collected and numerically scanned to estimate leaf

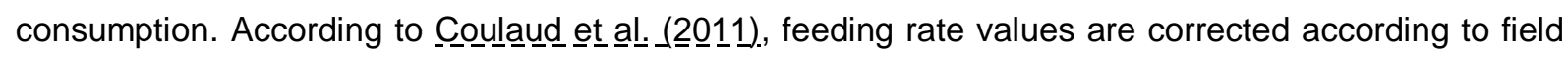
temperatures and body size of test orgnaisms,.

Molecular biomarkers 
Five pools of 5 male gammarids ( 15 to $20 \mathrm{mg}$ per male) were homogenized with a FastPrep- $24^{\mathrm{TM}}$ grinder in a microtube containing cold phosphate buffer $(100 \mathrm{mM} \mathrm{pH} 7.8,1: 10$ (w:v), 0.1\% Triton X100 , one steal ball $(4 \mathrm{~mm})$ and few glass balls $(2 \mathrm{~mm})$. Homogenates were then centrifuged at $4{ }^{\circ} \mathrm{C}$ for $15 \mathrm{~min}$ at $9000 \mathrm{xg}$ and the supernatant (post-mitochondrial fraction or S9) was conserved at $4{ }^{\circ} \mathrm{C}$ until enzymatic measurement.

The acetylcholinesterase activity (AChE) was determined according to Ellman et al. (1961) adapted to microplates (Xuereb et al., 2009). In a 96-well microtiter plate, $20 \mu \mathrm{L}$ of $0.0076 \mathrm{M}$ dithiobisnitrobenzoate, $20 \mu \mathrm{L}$ of $\mathrm{S} 9$ and $330 \mu \mathrm{L}$ of phosphate buffer $(0.1 \mathrm{M}, \mathrm{pH} 7.8)$ and $10 \mu \mathrm{L}$ of acetylthiocholine iodide solution were added. Hydrolysis to the yellow product 5-thio-2-nitro-benzoicacid was measured at $405 \mathrm{~nm}$ in a spectrophotometer every $30 \mathrm{~s}$ for $3 \mathrm{~min}$. AChE activity was expressed as nmoles of substrate hydrolyzed per minute.

The glutathione-S-transferase activity (GST) was measured according to (Habig et al., 1976) in 96 well microplates by adding $170 \mu \mathrm{L}$ of $2.2 \mathrm{mM}$ reduced glutathione, $10 \mu \mathrm{L}$ of $38 \mathrm{mM}$ 1-chloro-2.4dinitrobenzene, $150 \mu \mathrm{L}$ of $0.1 \mathrm{M}$ phosphate buffer and $20 \mu \mathrm{L}$ of the $1 / 8$ pre-diluted $\mathrm{S} 9$ fraction per well. GST activity was measured in a spectrophotometer at $340 \mathrm{~nm}$ every $30 \mathrm{~s}$ for $3 \mathrm{~min}$ and was expressed as nmoles of substrate hydrolyzed per mg of wet matter equivalent.

The analytical method for carboxylesterase activity (CE) measurement was developed by Ljungguisist and A A ugustinss son (1971) and then adapted to the microplate. Reacting with 4-Nitrophenyl acetate, carboxylesterase leads to the formation of yellow nitro phenol. Carboxylesterase was measured by adding $330 \mu \mathrm{l}$ of phosphate buffer $(0.1 \mathrm{M}, \mathrm{pH} 7.8), 15 \mu \mathrm{l}$ of the fraction $\mathrm{S} 9$ and $5 \mu \mathrm{l}$ of a solution of 4Nitrophenyl acetate (140 mM in DMSO). The absorbance was read at $405 \mathrm{~nm}$ at $20^{\circ} \mathrm{C}$ every 30 seconds, for 3 minutes. The activity was expressed in nmol of substrate hydrolyzed per minute and per mg of wet matter equivalent.

The phenol oxidase activity (PO) was measured according to Jansssens 96-well microtiter plates. $80 \mu \mathrm{l}$ of $5 \mathrm{mM}$ saline phosphate buffer (PBS, pH 7.4) and $15 \mu \mathrm{L}$ of S9 were added to each well. Then, $5 \mu \mathrm{L}$ of chymotrypsin solution $\left(5 \mathrm{mg} \mathrm{ml}^{-1}\right)$ were added and incubated for 5 min at room temperature to convert all pro-enzyme prophenoloxidase into phenoloxidase. Afterwards, $100 \mu \mathrm{L}$ of 3.4-dihydroxy-L-phenylalanine (1.97 mg. $\mathrm{ml}^{-1}$ in PBS) were added and the absorbance of the red colored dopachrome was measured in a spectrophotometer at $490 \mathrm{~nm}$ every $30 \mathrm{~s}$ during $3 \mathrm{~min}$ at $30{ }^{\circ} \mathrm{C}$. The phenol oxidase activity was expressed as nmoles of substrate hydrolyzed per minute per mg of wet matter equivalent.

\subsubsection{Dreissena polymorpha}

After 2 months of exposure, the zebra mussels were recovered, transported to the laboratory and kept in aerated aquariums (in the water coming from the site studied) for one day before the biological samples recovery. 
For each site, 9 pools per site of 3 digestive glands $(A)$ and nine pools of 3 whole organisms (B) were recovered and stored at $-80^{\circ} \mathrm{C}$. The samples " $A$ " were used to measure protein concentrations and various enzymes activities involved in energy acquisition (amylase, acid phosphatase "PAC", lipase and lactate dehydrogenase "LDH", aspartate transaminase "ASAT", alanine aminotransferase "ALAT" activities). The samples "B" were used to measure the available energy reserves (Ea) in mussel tissues (proteins, lipids, glycogen and glucose) and to evaluate the energy consumption (Ec) by measuring the activity of the electron transport system (ETS) (Hani et al., 2021). Finally, an integrative biomarker (CEA: cellular energy allocation) was calculated after determining Ea and Ec, according to the following formula: [CEA = Ea/Ec] (Verslycke et al., 2003). In addition to these biochemical biomarkers of energy metabolism, the mitochondrial ATP synthase (ATPase) and cytochrome-Coxidase (COX) gene expressions were measured by GPCR individually in the digestive glands of 10 mussels per site, following the protocol detailed in Louis__et al.__(20ㅡ는).

To assess the phagocytic efficiency of the hemocytes, hemolymph was withdrawn from mussel posterior muscle $(n=10)$. Immediately after the sample, each hemolymph sample quality was visually checked under an inverted microscope and cell count was performed using KOVA® Glasstic $\circledast$ slides with grids (Hycor Biomedical) according to the manufacturer's recommendations. The analyse of phagocytic activity was carried out in the same day using flow cytometer (Accuri ${ }^{\mathrm{TM}} \mathrm{C} 6$ flow cytometer, Becton Dickinson) in 96-well microplates with $100 \times 10^{3}$ cells/well. The protocol for the immune biomarkers assessment in the zebra mussels is detailed in Barihoux et al._(202020).

DNA strand breaks (representative of genotoxicity) were measured by the alkaline version of the comet assay $(\mathrm{pH}>13)$ in the circulating hemocytes collected in the same 10 mussels than the immune parameters. Cells mortality and concentration were assessed using flow cytometer (Accuri ${ }^{\text {TM }}$ C6 flow cytometer, Becton Dickinson) before performing the comet assay. The cell concentration was adjusted to a final concentration of $85000 \mathrm{cells} / \mathrm{mL}$ in a low melting point agarose $(0,7 \% \mathrm{w} / \mathrm{v})$, and the comet assay was performed with two $8 \mu \mathrm{L}$-minigels per mussel and a minimum of 100 nucleoids scored per minigel, following the methods described in Joachim_et_al. (2021) and in Louzon et al. (in prep). The level of DNA strand breaks was expressed as the mean percentage of tail intensity.

The phenol oxidase activity (PO), the Carboxylesterase activity (CE) and the glutathione-s-transferase activity (GST) were measured with the same method as described for G. fossarum previously.

\subsubsection{Fontinalis antipyretica}

After 4 weeks of exposure, bryophytes were recovered and 10 randomly selected stems were sampled from each sample and morphological traits were measured (Stem length and Stem number).

To analyze antioxidative defense activity of $F$. antipyretica, three enzymes were selected: Superoxidase dismutase (SOD, EC 1.15.1.1), Catalase (CAT, EC1.11.1.6) and Guaiacol peroxidase (GcPX, EC1.11.1.7). Two grams of $F$. antipyretica samples were weighted and crushed in a mortar placed on ice. Thereafter, the samples were suspended in $10 \mathrm{~mL} 80 \%(\mathrm{v} / \mathrm{v})$ phosphate buffer, at solid to solvent ratio of $1: 10(\mathrm{w} / \mathrm{v})$. After $24 \mathrm{~h}$ of maceration the supernatants 
were filtered through a Whatman GF/F glass microfiber filter $(0.7 \mu \mathrm{m})$. The resulting suspension was centrifuged at $15000 \times g$ for $10 \mathrm{~min}$ at $4{ }^{\circ} \mathrm{C}$ and supernatant stored at $-80^{\circ} \mathrm{C}$ until enzymes analyses.

The activities of the antioxidative enzymes superoxidase dismutase (SOD), Catalase (CAT) and

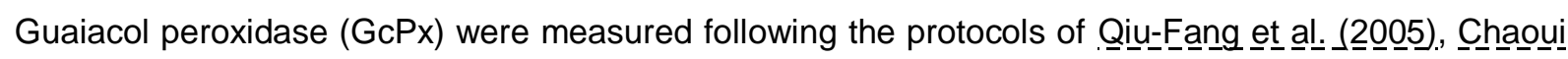
et__al._(1997) and Roy_et_al. (1992) adapted to F. antipyretica. These biomarkers were expressed by the protein concentration, measured using the Bradford method (Bradford, 1976).

Chlorophyll $\mathrm{a}$ and $\mathrm{b}$ were extracted according to method of Arnon_(1949) which involves maceration of the plant in acetone and calcium bicarbonate. After filtration and storage in a black box, the absorbance was then measured spectrophotometrically at 663 and $645 \mathrm{~nm}$.

The quantities of total chlorophylls and the chlorophyll $\mathrm{a} / \mathrm{b}$ ratios concentration $(\mathrm{mg} / \mathrm{g} \mathrm{FW}$ ) were determined by the equations proposed by Mackinney (1941). Determination of enzyme activity and chlorophyll measurements were performed in triplicate for each replicate.

\subsection{IBR calculations}

First, for each species, a reference value was defined for each biomarker (X0). Reference values for $G$. fossarum and $D$. polymorpha were determined for each biomarker based on the statistical method for determining threshold values described in Besse_et__al._(20132). For G. aculeatus and F. antipyretica, the references values were defined from a chosen reference group. For $G$. aculeatus, the reference group was the initial population maintained under control condition and sampled in the same period than the caging experiment. For $F$. antipyretica, the reference group came from the control condition of a mesocosm experimentation realised in the same year (Sossey Alaoui et al., 2021).

The Integrated Biomarker Response (IBRv2) (Sanchez et al., 2013) was calculated for each species to compare the global difference of biomarker levels on each studied site. From the measure of a biomarker $j(j=1 . . J)$ on an individual $i(i=1 . . n)$ of the species e $(e=1 . . E$, here $E=4)$ at the site $k(k=1 . . m$, here $m=5$ ) upstream or downstream of the WWTP ( $u=1$ for upstream and $u=2$ for downstream), called $X_{e, j, i, k, u}$, the IBRv2 index was calculated according to the following steps (Sanchez et al., 2013):

1) Calculation of the mean of each biomarker for the species e at the site $k$ (upstream or downstream) :

$$
\bar{X}_{e, j, k, u}=\frac{1}{n} \sum_{i=1}^{n} X_{e, j, i, k, u} \quad \text { Eq. (1) }
$$

2) Transformation into an induction/inhibition index regarding the reference value of the given biomarker:

$$
Y_{e, j, k, u}=\log \left(\frac{\bar{X}_{e, j, k, u}}{X 0_{e, j}}\right) \quad \text { Eq. (2) }
$$

3) Calculation of a deviation index to the reference:

$$
A_{e, j, k, u}=\frac{Y_{e, j, k, u}}{\sigma_{Y_{e, j}}} \quad \text { Eq. (3) }
$$


With $\sigma_{Y_{e, j}}$ the standard deviation of the Ye,j,k,u values among the $\mathrm{m}^{\star} 2$ localisations ( $\mathrm{m}$ sites, upstream and downstream) :

$\sigma_{Y_{e, j}}=\frac{1}{m * 2} \sqrt{\sum_{k=1}^{m} \sum_{u=1}^{2}\left(Y_{e, j, k, u}-\bar{Y}_{e, j}\right)^{2}}$ where $\bar{Y}_{e, j}$ is the mean of the Ye,j,k,u values among the $\mathrm{m} * 2$ localisations.

4) Calculation of the IBRv2 value for the species e at the site $k$ upstream or downstream:

$$
I_{e, k, u}=\sum_{j=1}^{J}\left|A_{e, j, k, u}\right| \quad \text { Eq. (4) }
$$

For each site, we thus obtained an IBRv2 value for each species upstream and downstream the WWTP. In order to compare the different rivers upstream from the WWTPs, we propose an integrated "multispecies" IBR value based on biomarkers modulation of the four species simultaneously. From the IBRv2 value calculated for each species at upstream localisation (each site upstream the WWTP) (Eq. 4), we first calculate the deviation of this value for each species regarding the mean of all upstream IBRv2 values of each species respectively (Eq. 5):

$$
F_{e, k, 1}=\frac{I_{e, k, 1}}{\Upsilon_{e}} \quad \text { Eq. (5) }
$$

where $\widehat{I_{e}}=\frac{1}{m} \sum_{k=1}^{m} I_{e, k, 1}$ is the mean, for each species, of the IBRv2 values estimated in all upstream sites.

Finally, a multispecies IBR value is obtained for each upstream site by summing the deviation values calculated before (Eq. 5) on all species:

$$
I M_{k}=\sum_{e=1}^{E} F_{e, k, 1} \quad \text { Eq. (6) }
$$

All the calculations were performed with R software version 3.3.2 (R Development Core Team, 2014). 


\section{RESULTS}

\subsection{Survival rate of animal species}

The survival rate at the end of the caging was high for G. aculeatus and D. polymorpha (always $>90 \%$ for both species which corresponds to a maximum of 2/30 dead fish and around 25/360 dead zebra mussels per site). A slight decrease of $D$. polymorpha survival rate was only observed downstream from the WWTP of Charleroi $(87.9 \%, 44 / 360$ dead). Concerning $G$. fossarum, their survival rate was usually lower than the other species and depended on the gender of individuals and the sites studied. Very satisfying survival rates were observed for both genders in the Helpe-Majeure at Avesnes-surHelpe $(\geq 85 \%)$. They were decreased in the Semois at Bouillon for both sexes, particularly downstream from the WWTP (Male: $81.3 \%$; Female: $71.4 \%$ ). The sites in the Meuse at Namur were very contrasted, with a satisfying survival rate for both sexes downstream from the WWTP (Male: 96.3\%; Female: 95.2\%) but a lower survival rate upstream from the WWTP, particularly for female individuals (76.2\%). Very satisfying survival rates were obtained in the Meuse at Charleville-Mézières for female individuals (>90\%) but they were lower for male individuals $(<75 \%)$. Finally, a weak survival rate was observed in female $G$. fossarum downstream from the WWTP of Charleroi with only $28.6 \%$ of surviving individuals (Table 3 ).

Table 3: Rate of survival of Gasterosteus aculeatus, Gammarus fossarum and Dreissena polymorpha caged in the sites studied. ND: No data, NC : not concerned.

\begin{tabular}{clcccc}
\hline \multirow{2}{*}{ Survival rate (\%) } & \multirow{2}{*}{ G. aculeatus } & \multicolumn{2}{c}{ G. fossarum } & \multirow{2}{*}{ D. polymorpha } \\
& & & Male & Female & \\
\hline \multirow{2}{*}{$\begin{array}{c}\text { Avesnes-sur- } \\
\text { Helpe }\end{array}$} & Upstream & 96.6 & 93.8 & 85.7 & $N C$ \\
& Downstream & 96.6 & 85 & 90.5 & $N C$ \\
\hline \multirow{2}{*}{ Bouillon } & Upstream & 96.6 & 88.8 & 81 & $N C$ \\
& Downstream & 92.9 & 81.3 & 71.4 & $N C$ \\
\hline \multirow{2}{*}{ Namur } & Upstream & 92.9 & 87.5 & 76.2 & 92.2 \\
& Downstream & 92.9 & 96.3 & 95.2 & 93.6 \\
\hline \multirow{2}{*}{$\begin{array}{c}\text { Charleville- } \\
\text { Mézières }\end{array}$} & Upstream & 96.6 & 73.8 & 90.5 & 93.1 \\
& Downstream & 96.6 & 72.5 & 95.2 & 93.6 \\
\hline \multirow{2}{*}{ Charleroi } & Upstream & $N D$ & $N D$ & $N D$ & 92.2 \\
& Downstream & $N D$ & 97.5 & 28.6 & 87.8 \\
\hline
\end{tabular}




\subsection{Biomarkers modulations upstream and downstream from the WWTP effluents}

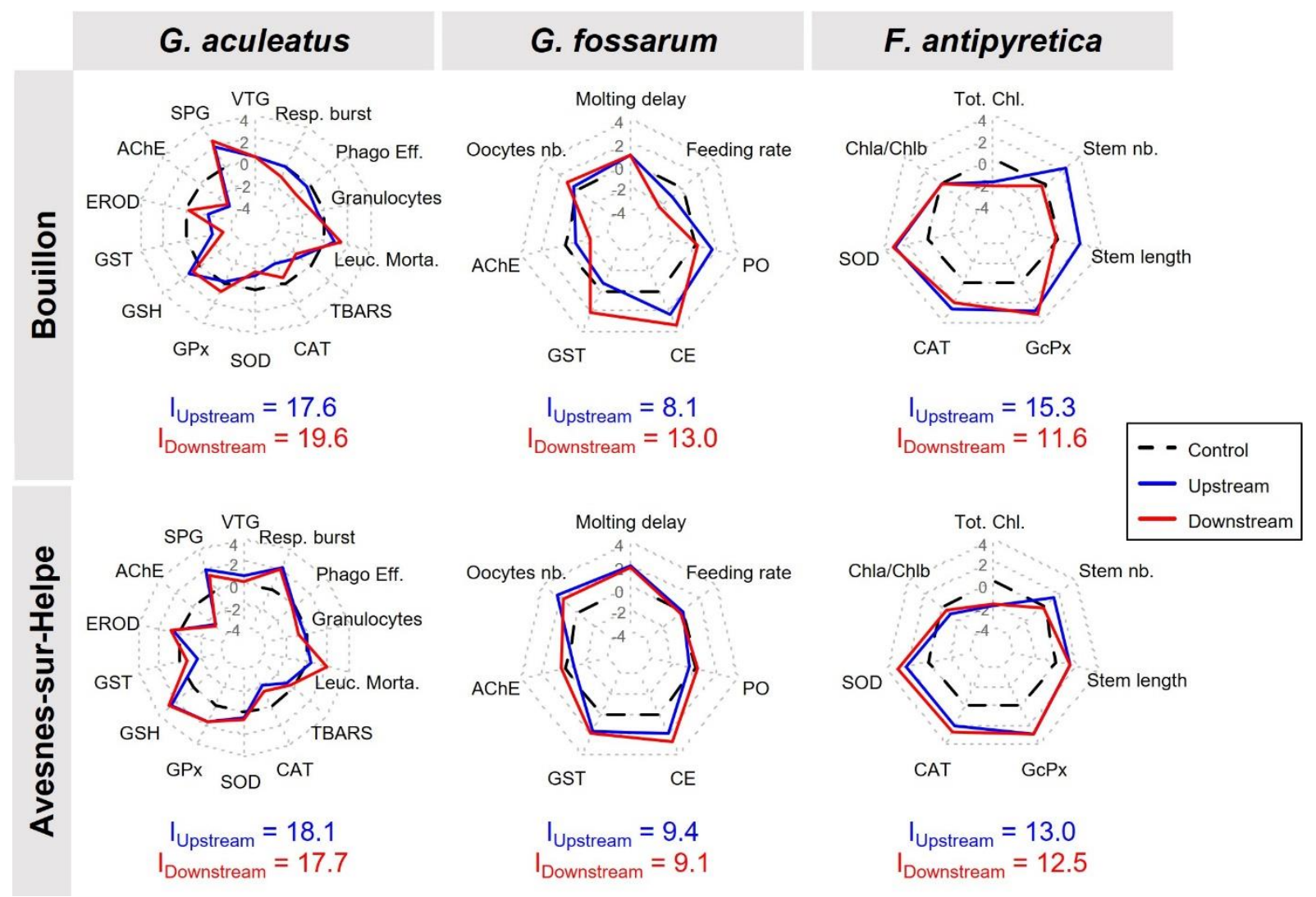

Fig. 2: IBRv2 calculation (Eq. 4) and starplot for each species caged upstream and downstream the WWTPs of Bouillon and Avesnes-sur-Helpe. The detailed deviation index (A, Eq. 3) are available in Table S2 and Table S3.

In the Helpe Majeure at Avesnes-sur-Helpe, the IBR index for the three species were very similar upstream and downstream from the effluent (difference < 0.5) which highlights the low effects in the receiving river of the WWTP effluent on the biomarkers assessed (Fig. 2).

In the Semois at Bouillon, the IBR values with $G$. aculeatus and $G$. fossarum were higher downstream from the effluent than upstream (G. aculeatus: $I_{\text {Upstream }}=17.6, I_{\text {Downstream }}=19.6 ; G$. fossarum: $I_{\text {Upstream }}=$ 8.1, I Iownstream $=13.0$ ). For $G$. aculeatus, the deleterious effects of effluent resulted in a decrease of innate immune capacities (increase in leucocytes mortality and decrease in the phagocytosis efficiency). For $G$. fossarum, it resulted rather in a worsening of effects measured in the individuals caged upstream from the effluent, namely a stronger inhibition of AChE activity and feeding rate as well as a stronger induction of biotransformation enzymes activities (GST and CE). On the contrary, the IBR index of $F$. antipyretica was higher upstream (I Ipstream $=15.3)$ than downstream (I Downstream $=$ 11.6) from the effluent. The standard stem length and number were more elevated upstream from the WWTP than downstream (Fig. 2). 


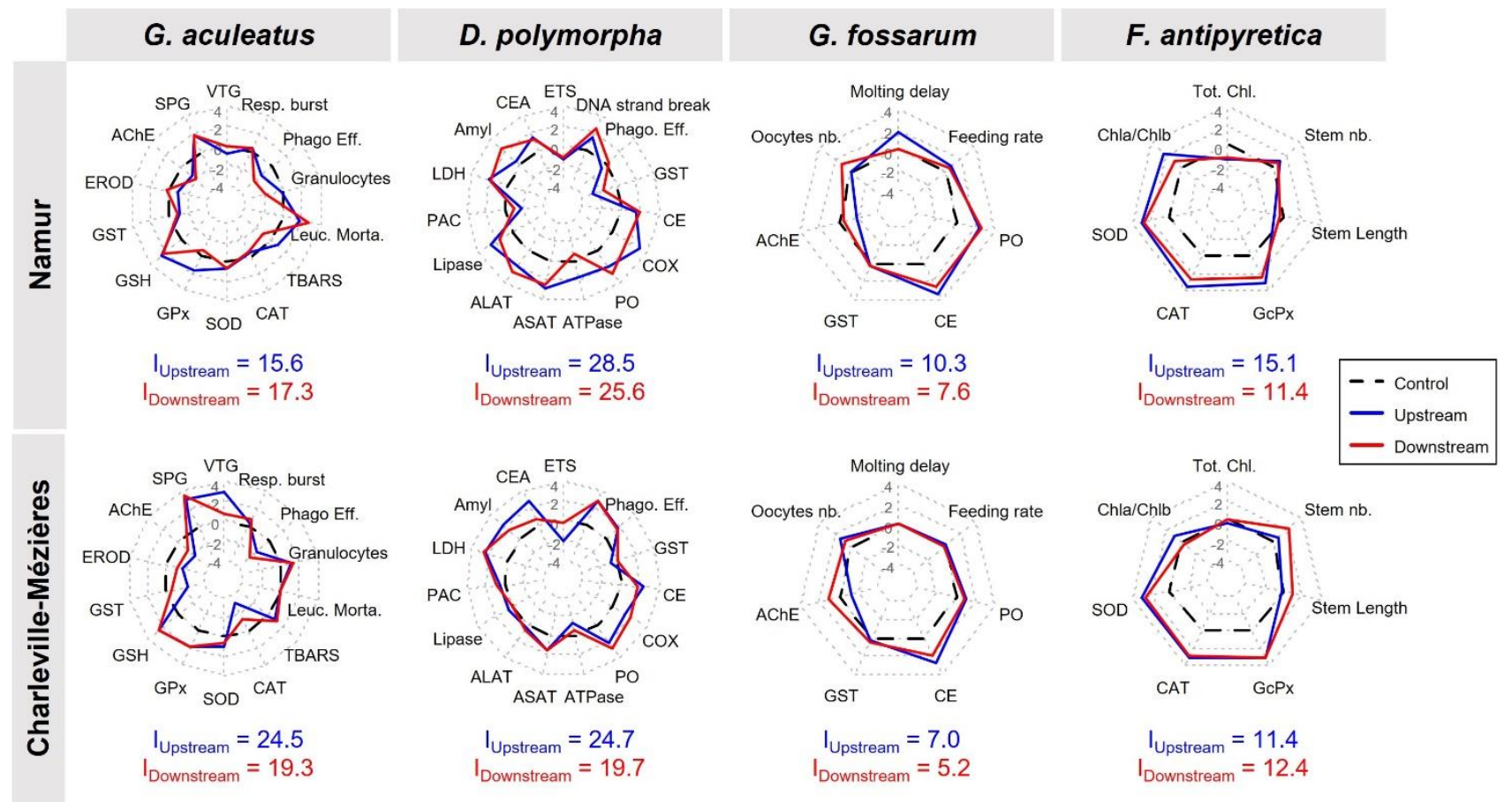

Fig. 3: IBRv2 calculation (Eq. 4) calculation and starplot for each species caged upstream and downstream the WWTPs of Namur and Charleville-Mézières. The detailed deviation index (A, Eq. 3) are available in Table S2 and Table S3.

In the Meuse at Namur, the IBR index for G. fossarum, D. polymorpha and F. antipyretica were higher upstream from the effluent than downstream (G. fossarum: $I_{\text {Upstream }}=10.3$ and $I_{\text {Downstream }}=7.6 ; D$. polymorpha: $I_{\text {Upstream }}=28.5$ and $I_{\text {Downstream }}=25.6 ; F$. antipyretica: $I_{\text {Upstream }}=15.1$ and $\left.I_{\text {Downstream }}=11.4\right)$. The molting delay and the AChE inhibition measured in G. fossarum upstream from the effluent were not highlighted downstream. D. polymorpha individuals have shown stronger energy metabolism perturbations (induction in lipase activity and in COX and ATPase genes expressions, inhibition of PAC activity) and a stronger GST inhibition upstream than downstream from the effluent. For its part, $F$. antipyretica presented a stronger modification of the chlorophyll a / chlorophyll b ratio upstream than downstream from the effluent. On the contrary, G. aculeatus was the only species that highlighted an effect of the WWTP effluent with a higher IBR value downstream from the effluent (I Downstream $=$ 17.3) than upstream $\left(I_{\text {Upstream }}=15.3\right)$. This deleterious effect was highlighted by a strong immunotoxicity downstream from the effluent, measured by an inhibition of phagocytosis efficiency, an increase in the leucocyte mortality and a modification in the leucocyte distribution (increase of the granulocyte/lymphocyte ratio) (Fig. 3).

In the Meuse at Charleville-Mézière, the IBR values were higher upstream from the WWTP effluent than downstream with $G$. aculeatus ( $\left.I_{\text {Upstream }}=24.5, I_{\text {Downstream }}=19.3\right), D$. polymorpha $\left(I_{\text {Upstream }}=24.7\right.$; $\left.I_{\text {Downstream }}=19.7\right)$ and $G$. fossarum ( $I_{\text {Upstream }}=7.0$; $\left.I_{\text {Downstream }}=5.2\right)$. G. aculeatus individuals have presented a slight induction in the VTG concentration upstream from the effluent that was not measured downstream. The biotransformation enzymes (EROD and GST), CAT and AChE activities were also stronger inhibited upstream than downstream from the effluent. For their part, the zebra mussels $D$. polymorpha have presented stronger energy metabolism perturbations upstream from the 
effluent than downstream, especially with a higher induction of CEA and amylase activity as well as an inhibition of ETS activity. Finally, the inhibition of AChE activity measured upstream from the effluent in $G$. fossarum was no longer measured downstream. Unlike animal species, the IBR value in $F$. antipyretica was higher downstream $\left(\mathrm{I}_{\text {Downstream }}=12.4\right)$ than upstream from the effluent (I Upstream $=$ 11.4). The standard length and the number of stems were closer of the reference downstream from the effluent than upstream (Fig. 3).

In the Sambre at Charleroi, the cages containing G. fossarum individuals could unfortunately not be recovered upstream from the WWTP. Consequently, the effects of this WWTP effluent can only be investigated according to the biomarkers in $D$. polymorpha. The IBR value for this specie was slightly higher downstream from the WWTP $\left(I_{\text {Downstream }}=21.4\right)$ than upstream $\left(I_{\text {Upstream }}=20.2\right)$. This effluent effect was mainly due to the increase in CE activity and the decrease of the phagocytosis efficiency (Fig. 4).

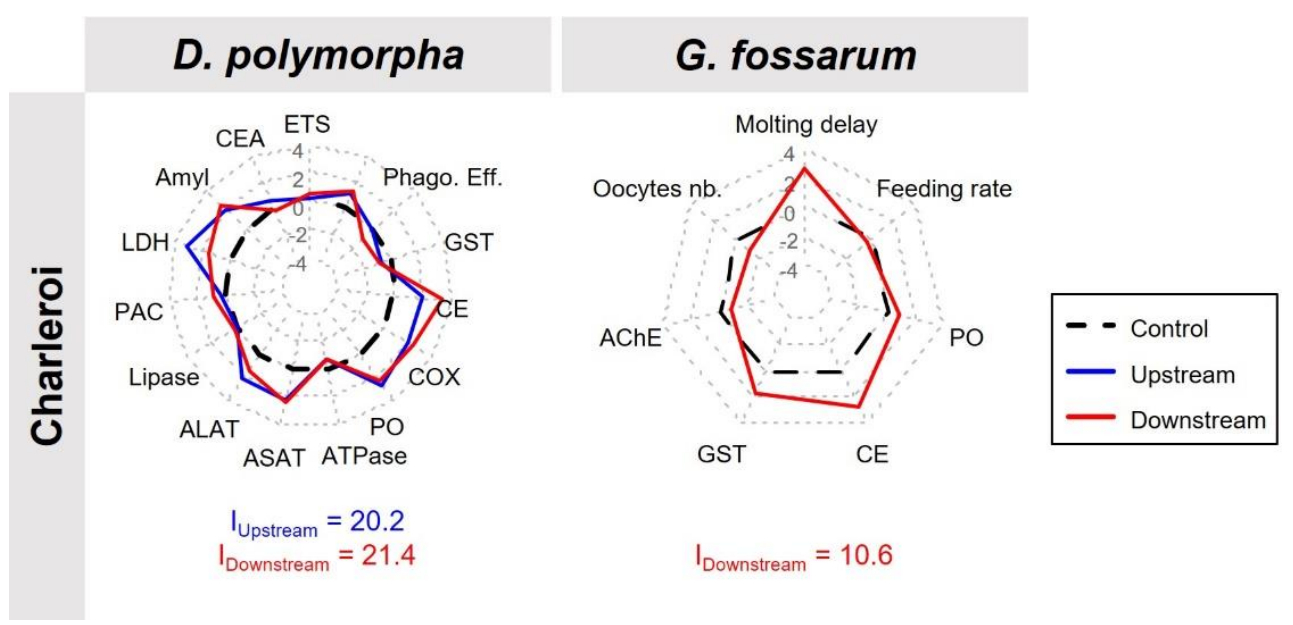

Fig. 4: IBRv2 calculation (Eq. 4) and starplot for Dreissena polymorpha and Gammarus fossarum caged upstream and downstream the WWTPs of Charleroi. The detailed deviation index (A, Eq. 3) are available in Table S2 and Table S3. 


\subsection{Classification of the rivers following the model species}

To classify the different rivers, only upstream sites which correspond to the water quality upstream from the WWTPs have been kept. Moreover, only the sites where G. fossarum, G. aculeatus and $F$. antipyretica were caged have been considered (Charleville-Mézière, Namur, Avesnes-sur-Helpe) to keep focus on the three species cages on $4 / 5$ of the sites studied. On the basis of the individual IBR values, a "multispecies" IBR index (Eq. 6) is proposed to compare the 4 sites according to the whole results of the three species (Table 4).

Table 4: The individual (I index, Eq. 4) and multispecies IBR values (IM in Eq. 6) for the sites upstream the WWTP of Bouillon, Avesnes-sur-Helpe, Namur and Charleville-Mézière.

\begin{tabular}{ccccc}
\hline & \multicolumn{3}{c}{ Individual IBR values (I) } & Multispecies \\
& G. aculeatus & G. fossarum & F. antipyretica & IBR values (IM) \\
\hline $\begin{array}{c}\text { Semois } \\
\text { (Bouillon) }\end{array}$ & 17.6 & 8.1 & 15.3 & $\mathbf{2 . 9 8}$ \\
$\begin{array}{c}\text { Helpe-Majeure } \\
\text { (Avesnes-sur-Helpe) }\end{array}$ & 18.1 & 9.4 & 13.0 & $\mathbf{2 . 9 9}$ \\
\hline $\begin{array}{c}\text { Meuse } \\
\text { (Namur) }\end{array}$ & 15.6 & 10.3 & 15.1 & $\mathbf{3 . 1 1}$ \\
\hline $\begin{array}{c}\text { Meuse } \\
\text { (Charleville-Mézière) }\end{array}$ & 24.5 & 7.0 & 11.4 & $\mathbf{2 . 9 2}$ \\
\hline
\end{tabular}

The multispecies IBR indicates that the Meuse at Namur was the site which have induced the stronger biological impacts $(I M=3.11)$. This site is downgraded based on results highlighted in $G$. fossarum $(I=$ $10.3)$ and in $F$. antipyretica $(I=15.1)$. In $G$. fossarum, a high induction of the CE activity associated with a decrease in the AChE activity was measured. In addition, an increase in the molting delay, in the PO activity and in the feeding rate was recorded. In F. antipyretica, all biomarkers were strongly modulated, especially the antioxidative defenses which have presented high inductions. An increase of the $\mathrm{Chl} \mathrm{a} \mathrm{/} \mathrm{Chl} \mathrm{b} \mathrm{ratio,} \mathrm{the} \mathrm{number} \mathrm{of} \mathrm{stem} \mathrm{and} \mathrm{a} \mathrm{decrease} \mathrm{of} \mathrm{the} \mathrm{total} \mathrm{chlorophyll} \mathrm{concentration} \mathrm{and}$ the total stem length were also measured. On the contrary, the Meuse at Namur appeared to be the least deteriorated site regarding the biomarkers responses in $G$. aculeatus $(I=15.60)$, even if a lot of biomarkers were modulated, namely immune parameters (high leucocyte mortality and low phagocytosis efficiency), AChE activity (inhibition), GSH concentration and GPx activity (induction for both).

The multispecies IBR highlights that the Meuse at Charleville-Mézière was the site with the lowest impacts on the biomarkers ( $I M=2.92$ ). This ranking is due to the results in $G$. fossarum and $F$. antipyretica. This site was the least deteriorated regarding $G$. fossarum $(I=7.0)$ with only an induction of the CE activity recorded. In the same way, it was also the least deteriorated site according to the $F$. antipyretica (IBR = 11.4) in which induction of antioxidative enzymes (CAT, SOD, GcPx) and induction of stem number and length were measured. As for Namur, the results were opposite for G. aculeatus in which strong modulations have been highlighted. Indeed, the Meuse at Charleville-Mézière appeared as the most deteriorated site with the biomarker responses in the sticklebacks (IBR = 
24.50). The measured perturbations were characterised by a high VTG concentration in males, low EROD, GST, CAT and AChE activities, a high GPx activity associated with a high GSH and TBARS content.

The Semois and the Helpe-Majeure are middle ranked with similar values for the multispecies IBR, respectively equal to 2.98 and 2.99 . These rivers are middle ranked both in $G$. aculeatus (Semois : $\mathrm{IBR}=17.6$; Helpe-majeure : IBR = 18.1) and $G$. fossarum (Semois : IBR = 8.1; Helpe-majeure : IBR $=9.4$ ) but the Semois was the highest deteriorated site regarding to $F$. antipyretica $(I B R=15.3)$. The stickleback caged in the Semois at Bouillon have presented a decrease in biotransformation enzymes activities (EROD and GST), in antioxidant enzymes activities (SOD, CAT), in TBARS content and in AChE activity. In G. fossarum, an increase in PO and CE activities was measured associated with a reduction of the feeding rate and $\mathrm{AChE}$ activity. F. antipyretica have presented a strong induction of antioxidative enzymes, number and length of stem as well as a decrease in the concentration of total chlorophyll. The downgrading of the Helpe-Majeure with $G$. aculeatus rested on the high respiratory burst index, the high GPx activity and GSH content and the low CAT and AChE activities. As for G. aculeatus, perturbations in antioxidative enzymes were measured in $F$. antipyretica (high SOD, CAT and GcPx activities), in addition to a low total chlorophyll concentration. According to G. fossarum, the downgrading of the Helpe-Majeure was linked with the high GST and CE activities, the high molting delay and the high oocytes number in female individuals

\section{DISCUSSION}

\subsection{Applicability of multispecies caging for the biomonitoring}

Active biomonitoring is a relevant alternative to overcome limitations associated with the passive approach. (number, size, and age variability of the sampled individuals, acclimatization or adaptation of native populations to chronic contamination). However, all active biomonitoring studies in aquatic environments focus only on a single species belonging to a single biological compartment. The variability of the response to contamination between different species is few questioned and integrated. As part of the DIADeM program, the main objective was to demonstrate that species diversity in biomonitoring, through active biomonitoring approach, is relevant and improve diagnostic of aquatic systems. Survival rates were rather high for all three animal species, especially $G$. aculeatus and D. polymorpha for which survival rates mostly exceeded $90 \%$. The caging of G. aculeatus individuals was successful at all sites, even in large and deep river with high flow rate. The study demonstrates the wide use range of these four model species together, which can be caged both in small and large systems with a variability in physicochemical parameters and chemicals contamination. This study has demonstrated the technical feasibility of the multispecies caging with several species belonging to various biological groups. 


\subsection{Characterization of effluents impacts with the different species}

Biomarkers assessed in the three animal species (G. aculeatus, D. polymorpha, G. fossarum) were diversified and complementary, the result of many years of use in biomonitoring studies. On the contrary, biomarkers are more rarely and recently studied in $F$. antipyretica. As a result, the battery of biomarkers in $F$. antipyretica in DIADeM program is less diversified than in other species. Consequently, the adverse effect of WWTPs effluents and the global contamination of the rivers were far less highlighted with $F$. antipyretica than with other species. No upstream/downstream differences were shown in the antioxidative enzymes activities, which have presented strong inductions in comparison to the reference, whatever the site investigated. In the same way, no difference in the total chlorophyll concentration was shown. The chl a / chl b ratio was the only biomarker induced downstream from the WWTP of Namur, which could be indicative of a decrease in the light exposure (Leong and Anderson, 1984). Among all the biomarkers assessed in F. antipyretica, the stem length and number appeared as the only ones that have presented some differences between the sites upstream and downstream from the WWTP (especially in Bouillon and Charleville-Mézières). However, these two parameters are only morphological indicators that give no information about the physiological function or the cellular compartment impacted by the pollution. It should also be noted that availability of contaminants and the uptake of these by moss can be affected by some characteristics of the sampling site including highly variable flow throughout the water column, the depth and width of the river. The depth for example should be sufficient to ensure that the moss is submerged throughout the exposure period. This factor differs among the exposure sites and it was low in the Semois at Bouillon and Avesnes-sur-Helpe which were in low-water periods during the exposure which may have affected the uptake of the pollutants by the plant. In addition, the amount of moss used was $200 \mathrm{~g} / \mathrm{cage}$ which probably prevent a better circulation of water in the moss mass and limit assimilation of pollutants to those close to the inner surface of the bags (Ares et al., 2014; Kelly and Whitton, 1987). This phenomenon can be observed mainly in shallow slow current rivers.

The caging of the three animal species has conducted to similar conclusions concerning the WWTPs effluents effects in Avesnes-sur-Helpe, Charleville-Mézières and Bouillon. In Avesnes-sur-Helpe, the calculated IBR values for all species were not different between the upstream and downstream site. No upstream/downstream difference have hence been highlighted whatever the model species. In the Meuse at Charleville-Mézières, the three animal species have presented stronger modulations of biomarkers upstream than downstream from the WWTP. The results were similar for the three species even if this upstream/downstream discrepancy was weaker in G. fossarum. This underlines the absence of adverse effect coming from the effluent, or even a dilution of the contamination already existing upstream from the river. These results were consistent with the chemical characterisation of these sites, which did not highlight an increase of contamination downstream from the WWTP. G. fossarum and G. aculeatus have shown similar results in the Semois at Bouillon, with a highlight of the effluents impacts on the exposed organisms. These results are consistent with the chemical analyses which have shown an increase of contamination downstream from the effluent compared to the upstream site. Some biomarker responses were similar in both species, such as the inhibition of AChE 
activity downstream from the WWTP and the induction of CE activity in G. fossarum, suggesting the presence and impacts by pesticides contamination (Fulton and Key, 2001; Wheelock et al., 2008). Other biomarker responses have presented an opposite modulation, such as the GST activity which was induced in $G$. fossarum but inhibited in $G$. aculeatus, underlining specie-specificity of biological responses towards contamination. On the contrary to other sites, the results for the Meuse at Namur was variable according to the species. G. aculeatus was the only species that highlighted adverse effects of the WWTP's effluent, especially a strong immunotoxicity. This result was consistent with the chemical contamination, which was higher downstream from the WWTP than upstream. These immunotoxic effects were already observed on fish exposed to urban effluents (Kakuta, 1997; Ménard et al., 2010). They can be linked with many different chemicals potentially found in the effluent and known to modulate the immune system (i.e. pesticides, PAH, metals) (Ahmed, 2000; Bols et al., 2001). On the contrary, the biomarker measurement in $G$. fossarum and $D$. polymorpha tended to show an absence of effluent effects, even a reduction of the deleterious effects measured upstream from the effluent.

\subsection{A multispecies IBR to assess the water quality of rivers}

The used of generic reference values (D. polymorpha, $G$. fossarum) or references independent of the dataset ( $G$. aculeatus, $F$. antipyretica) allow to interpret the biomarkers responses upstream from the WWTPs effluents and thus assess the quality of the receiving environment. This assessment of the receiving environment is an essential point in the final diagnosis of an effluent impact. In the present study, the IBR values were high for all rivers, even upstream from the WWTPs, suggesting a chemical contamination independent of the chemical pollution induced by the WWTPs. This is especially true in the Meuse at Namur that appeared as the site with the strongest biological modulations in $G$. fossarum, $F$. fontinalis and even $D$. polymorpha. The contamination of the receiving environment is confirmed by the chemical analyses which have shown high levels of pharmaceuticals and domestic tracers in the Sambre and in the Meuse at Namur, downstream the confluence with the Sambre. This contamination of the receiving environment can explain that the most part of tests species did not highlight an increase of the toxicity downstream the WWTP of Namur. Indeed, the potential impact of an effluent cannot be pointed because the water quality of the receiving environment is already downgraded. The assessment of the receiving environment quality offers the opportunity to determine its vulnerability towards inputs of chemicals contaminants.

The multispecies IBR value proposed in this study (Eq. 6) allows to assess the receiving environment quality by integrating the whole results for three of the four tests species caged in the upstream sites. Considering the multispecies IBR values, the Meuse upstream from the WWTP of Namur appeared as the river with the strongest biological impacts, even if the results varied according to the model species. This result is concordant with the chemical analysis which have shown that the Meuse at Namur presented the highest contaminants concentration among the four sites studied in this part. The multispecies IBR have also shown that the biological modulations were the lowest in the Meuse at 
Charleville-Mézière. As for upstream/downstream modulations, the final results varied according to the species, with an opposite ranking between $G$. aculeatus and $G$. fossarum/F. antipyretica.

\subsection{Complementarity of the model species and further perspectives}

Finally, biomarker results highlighted in upstream/dowmstream modulation and in the quality of the receiving environment have shown discrepancies between the different species. These disparities may be linked to the exposure pathways of the model species. Whereas a bryophyte will be exclusively subjected to direct exposure to contaminants, animal species can also be exposed through their feed. These exposure pathways are themselves dependent on the trophic level and on the diet of the species (i.e. filter feeder, detritivore, carnivore). This variability in exposure to contaminants can induce interspecific discrepancies in the measured biological responses. Specific differences in the sensibility to contaminants can lead to various physiological modulations as well. Thus, the use of several complementary biological groups representatives of diverse trophic levels and diverse sensibility appears essential to assess the toxic effects of pollution on the ecosystem as a whole.

In addition, the investigated physiological functions in each species have played an important role in the final diagnosis. Indeed, an imbalance in the physiological functions assessed can be noticed between the species. Immune function was less investigated in $G$. fossarum and D. polymorpha than in $G$. aculeatus, which respectively have just one (PO) and two (phagocytosis efficiency and PO) biomarkers. The immunotoxic damages were thus further highlighted and considered in the final diagnosis with $G$. aculeatus than with the other species. In the same way, energy metabolism represents two thirds of the biomarker assessed in $D$. polymorpha whereas this major physiological function is not assessed in G. aculeatus. This underlines the need to improve the biomarker sets measured in all species to include a large variety of physiological functions and/or to highlight various mechanism of toxicity. In this context, the proteomic approach appear to be promising tools to develop new biomarkers (Leprêtre et al., 2020; Trapp et al., 2014). The proteomic approach involves a step of drawing up of the catalogue of proteins available in a sentinel species (Shotgun proteomics) before processing targeted proteins assays (several hundreds of peptides can be assessed). This multiplexed assay approach allows to overcome some obstacles relating to the targeted biomarker measurements (multiplicity and diversity of methodology between several laboratories, under-representation of some physiological functions). The improvement of the biomarker sets would strengthen the interest to consider several species to take into account the differences of sensibility in the final diagnosis. The multispecies approach could thus be widespread in active biomonitoring studies to accurately assess the impacts of a contamination on an ecosystem as a whole.

\section{$\underline{\text { Acknowledgments }}$}

This work was carried out within the framework of the DIADEM project (« Development of an integrated approach for the diagnosis of the water quality of the River Meuse ») and was supported by 
the Interreg France-Wallonia-Vlaanderen Programme (European Regional Development Fund-ERDF) and the French Ministry in charge of ecology. 


\section{References}

Aarab, N., Champeau, O., Mora, P., Daubeze, M., Garrigues, P., Narbonne, J.-F., 2004. Scoring approach based on fish biomarkers applied to French river monitoring. Biomarkers 9, 258-270. https://doi.org/10.1080/13547500400015626

Adams, S.M., Brown, A.M., Goede, R.W., 1993. A Quantitative Health Assessment Index for Rapid Evaluation of Fish Condition in the Field. Transactions of the American Fisheries Society 122, 63-73. https://doi.org/10.1577/15488659(1993)122<0063:AQHAIF>2.3.CO;2

Ahmed, S.A., 2000. The immune system as a potential target for environmental estrogens (endocrine disrupters): a new emerging field. Toxicology 150, 191-206. https://doi.org/10.1016/S0300-483X(00)00259-6

Ares, A., Fernández, J.A., Carballeira, A., Aboal, J.R., 2014. Towards the methodological optimization of the moss bag technique in terms of contaminants concentrations and replicability values. Atmospheric Environment 94, 496-507. https://doi.org/10.1016/j.atmosenv.2014.05.066

Arnon, D.I., 1949. Copper enzymes in isolated chloroplasts, polyphenoloxidase in Beta vulgaris. Plant Physiol 24, 1-15.

Augusto, S., Gonzalez, C., Vieira, R., Máguas, C., Branquinho, C., 2011. Evaluating Sources of PAHs in Urban Streams Based on Land Use and Biomonitors. Environ. Sci. Technol. 45, 3731-3738. https://doi.org/10.1021/es1036332

Augusto, S., Máguas, C., Branquinho, C., 2013. Guidelines for biomonitoring persistent organic pollutants (POPs), using lichens and aquatic mosses - A review. Environmental Pollution 180, 330-338. https://doi.org/10.1016/j.envpol.2013.05.019

Bado-Nilles, A., Betoulle, S., Geffard, A., Porcher, J.-M., Gagnaire, B., Sanchez, W., 2013. Flow cytometry detection of lysosomal presence and lysosomal membrane integrity in the three-spined stickleback (Gasterosteus aculeatus L.) immune cells: applications in environmental aquatic immunotoxicology. Environmental Science and Pollution Research 20, 2692-2704. https://doi.org/10.1007/s11356-012-1410-2

Bado-Nilles, A., Jolly, S., Porcher, J.-M., Palluel, O., Geffard, A., Gagnaire, B., Betoulle, S., Sanchez, W., 2014. Applications in environmental risk assessment of leucocyte apoptosis, necrosis and respiratory burst analysis on the European bullhead, Cottus sp. Environmental Pollution 184, 9-17. https://doi.org/10.1016/j.envpol.2013.07.049

Barjhoux, I., Rioult, D., Geffard, A., Palos Ladeiro, M., 2020. A new protocol for the simultaneous flow cytometric analysis of cytotoxicity and immunotoxicity on zebra mussel (Dreissena polymorpha) hemocytes. Fish Shellfish Immunol 98, 224235. https://doi.org/10.1016/j.fsi.2019.12.092

Beliaeff, B., Burgeot, T., 2002. Integrated biomarker response: A useful tool for ecological risk assessment. Environmental Toxicology and Chemistry 21, 1316-1322. https://doi.org/10.1002/etc.5620210629

Besse, J.-P., Coquery, M., Lopes, C., Chaumot, A., Budzinski, H., Labadie, P., Geffard, O., 2013. Caged Gammarus fossarum (Crustacea) as a robust tool for the characterization of bioavailable contamination levels in continental waters: Towards the determination of threshold values. Water Research 47, 650-660. https://doi.org/10.1016/j.watres.2012.10.024

Blum, K.M., Andersson, P.L., Ahrens, L., Wiberg, K., Haglund, P., 2018. Persistence, mobility and bioavailability of emerging organic contaminants discharged from sewage treatment plants. Science of The Total Environment 612, 1532-1542. https://doi.org/10.1016/j.scitotenv.2017.09.006

Bols, N.C., Brubacher, J.L., Ganassin, R.C., Lee, L.E.J., 2001. Ecotoxicology and innate immunity in fish. Developmental \& Comparative Immunology 25, 853-873. https://doi.org/10.1016/S0145-305X(01)00040-4

Bradford, M.M., 1976. A rapid and sensitive method for the quantitation of microgram quantities of protein utilizing the principle of protein-dye binding. Analytical Biochemistry 72, 248-254. https://doi.org/10.1016/0003-2697(76)90527-3

Broeg, K., Westernhagen, H. v, Zander, S., Körting, W., Koehler, A., 2005. The "bioeffect assessment index" (BAl): A concept for the quantification of effects of marine pollution by an integrated biomarker approach. Marine Pollution Bulletin 50, 495503. https://doi.org/10.1016/j.marpolbul.2005.02.042

Bruns, I., Friese, K., Markert, B., Krauss, G.-J., 1997. The use of Fontinalis antipyretica L. ex Hedw. as a bioindicator for heavy metals. 2. Heavy metal accumulation and physiological reaction of Fontinalis antipyretica L. ex Hedw. in active biomonitoring in the River Elbe. Science of The Total Environment 204, 161-176. https://doi.org/10.1016/S00489697(97)00174-5

Cao, R., Wang, D., Wei, Q., Wang, Q., Yang, D., Liu, H., Dong, Z., Zhang, X., Zhang, Q., Zhao, J., 2018. Integrative Biomarker Assessment of the Influence of Saxitoxin on Marine Bivalves: A Comparative Study of the Two Bivalve Species Oysters, Crassostrea gigas, and Scallops, Chlamys farreri. Front. Physiol. 9. https://doi.org/10.3389/fphys.2018.01173

Catteau, A., Bado-Nilles, A., Beaudouin, R., Joachim, S., Palluel, O., Turiès, C., Galet, C., Geffard, A., Porcher, J.-M., 2020. An active biomonitoring approach using three-spined stickleback (Gasterosteus aculeatus, L.) to assess the efficiency of a constructed wetland as tertiary treatment of wastewater. Ecological Indicators 114, 106238. https://doi.org/10.1016/j.ecolind.2020.106238

Catteau, A., Bado-Nilles, A., Beaudouin, R., Tebby, C., Joachim, S., Palluel, O., Turiès, C., Chrétien, N., Nott, K., Ronkart, S., Geffard, A., Porcher, J.-M., 2021. Water quality of the Meuse watershed: Assessment using a multi-biomarker approach with caged three-spined stickleback (Gasterosteus aculeatus L.). Ecotoxicol Environ Saf 208, 111407. https://doi.org/10.1016/j.ecoenv.2020.111407

Catteau, A., Le Guernic, A., Marchand, A., Hani, Y.M.I., Palluel, O., Turiès, C., Bado-Nilles, A., Dedourge-Geffard, O., Geffard, A., Porcher, J.-M., 2019. Impact of confinement and food access restriction on the three-spined stickleback (Gasterosteus aculeatus, L.) during caging: a multi-biomarker approach. Fish Physiol Biochem. https://doi.org/10.1007/s10695-01900670-1 
Chaoui, A., Mazhoudi, S., Ghorbal, M.H., El Ferjani, E., 1997. Cadmium and zinc induction of lipid peroxidation and effects on antioxidant enzyme activities in bean (Phaseolus vulgaris L.). Plant Science 127, 139-147. https://doi.org/10.1016/S01689452(97)00115-5

Coulaud, R., Geffard, O., Xuereb, B., Lacaze, E., Quéau, H., Garric, J., Charles, S., Chaumot, A., 2011. In situ feeding assay with Gammarus fossarum (Crustacea): Modelling the influence of confounding factors to improve water quality biomonitoring. Water Research 45, 6417-6429. https://doi.org/10.1016/j.watres.2011.09.035

Dagnino, A., Allen, J.I., Moore, M.N., Broeg, K., Canesi, L., Viarengo, A., 2007. Development of an expert system for the integration of biomarker responses in mussels into an animal health index. Biomarkers 12, $155-172$. https://doi.org/10.1080/13547500601037171

Dazy, M., Masfaraud, J.-F., Férard, J.-F., 2009. Induction of oxidative stress biomarkers associated with heavy metal stress in Fontinalis antipyretica Hedw. Chemosphere 75, 297-302. https://doi.org/10.1016/j.chemosphere.2008.12.045

De Kermoysan, G., Pery, A., Porcher, J.-M., Beaudouin, R., 2013. A non-invasive method based on head morphology to sex mature three-spined stickleback (Gasterosteus aculeatus L.) in rearing conditions. Mathematical Biosciences 244, 148153. https://doi.org/10.1016/j.mbs.2013.05.001

de Lafontaine, Y., Gagne, F., Blaise, C., Costan, G., Gagnon, P., Chan, H.M., 2000. Biomarkers in zebra mussels (Dreissena polymorpha) for the assessment and monitoring of water quality of the St Lawrence River (Canada). Aquatic Toxicology 22.

Dedourge-Geffard, O., Palais, F., Biagianti-Risbourg, S., Geffard, O., Geffard, A., 2009. Effects of metals on feeding rate and digestive enzymes in Gammarus fossarum: An in situ experiment. Chemosphere 77, 1569-1576. https://doi.org/10.1016/j.chemosphere.2009.09.042

Evariste, L., David, E., Cloutier, P.-L., Brousseau, P., Auffret, M., Desrosiers, M., Groleau, P.E., Fournier, M., Betoulle, S., 2018. Field biomonitoring using the zebra mussel Dreissena polymorpha and the quagga mussel Dreissena bugensis following immunotoxic reponses. Is there a need to separate the two species? Environmental Pollution 238, 706-716. https://doi.org/10.1016/j.envpol.2018.03.098

Friberg, N., Andersen, T.H., Hansen, H.O., Iversen, T.M., Jacobsen, D., Krøjgaard, L., Larsen, S.E., 1994. The effect of brown trout (Salmo Trutta L.) on stream invertebrate drift, with special reference to Gammarus pulex L. Hydrobiologia 294, 105110. https://doi.org/10.1007/BF00016850

Fulton, M.H., Key, P.B., 2001. Acetylcholinesterase inhibition in estuarine fish and invertebrates as an indicator of organophosphorus insecticide exposure and effects. Environmental Toxicology and Chemistry 20, 37-45. https://doi.org/10.1002/etc.5620200104

Gagnaire, B., Bado-Nilles, A., Betoulle, S., Amara, R., Camilleri, V., Cavalié, I., Chadili, E., Delahaut, L., Kerambrun, E., Orjollet, D., Palluel, O., Sanchez, W., 2015. Former uranium mine-induced effects in caged roach: a multiparametric approach for the evaluation of in situ metal toxicity. Ecotoxicology 24, 215-231. https://doi.org/10.1007/s10646-014-1374-8

Galloway, T.S., Brown, R.J., Browne, M.A., Dissanayake, A., Lowe, D., Jones, M.B., Depledge, M.H., 2004. A Multibiomarker Approach To Environmental Assessment. Environ. Sci. Technol. 38, 1723-1731. https://doi.org/10.1021/es030570+

Galoux, D., Chérot, F., Rosillon, F., Sossey-Alaoui, K., 2015. Contribution to the Macrophytic Typology of Belgian Reference Watercourses. Advances in Botany 2015, e651369. https://doi.org/10.1155/2015/651369

Geffard, O., Xuereb, B., Chaumot, A., Geffard, A., Biagianti, S., Noël, C., Abbaci, K., Garric, J., Charmantier, G., CharmantierDaures, M., 2010. Ovarian cycle and embryonic development in Gammarus fossarum: Application for reproductive toxicity assessment. Environmental Toxicology and Chemistry 29, 2249-2259. https://doi.org/10.1002/etc.268

Gouveia, D., Chaumot, A., Charnot, A., Almunia, C., François, A., Navarro, L., Armengaud, J., Salvador, A., Geffard, O., 2017. Ecotoxico-Proteomics for Aquatic Environmental Monitoring: First in Situ Application of a New Proteomics-Based Multibiomarker Assay Using Caged Amphipods. Environ. Sci. Technol. 51, 13417-13426. https://doi.org/10.1021/acs.est.7b03736

Habig, W.H., Pabst, M.J., Jakoby, W.B., 1976. Glutathione S-transferase AA from rat liver. Arch Biochem Biophys 175, 710716. https://doi.org/10.1016/0003-9861(76)90563-4

Hagger, J.A., Jones, M.B., Lowe, D., Leonard, D.R.P., Owen, R., Galloway, T.S., 2008. Application of biomarkers for improving risk assessments of chemicals under the Water Framework Directive: A case study. Marine Pollution Bulletin 56, 11111118. https://doi.org/10.1016/j.marpolbul.2008.03.040

Hani, Y.M.I., Prud'Homme, S.M., Nuzillard, J.-M., Bonnard, I., Robert, C., Nott, K., Ronkart, S., Dedourge-Geffard, O., Geffard, A., 2021. 1H-NMR metabolomics profiling of zebra mussel (Dreissena polymorpha): A field-scale monitoring tool in ecotoxicological studies. Environmental Pollution 270, 116048. https://doi.org/10.1016/j.envpol.2020.116048

International Meuse Commission, 2005. International River Basin District Meuse - Characteristics, Review of the Environmental Impact of Human Activity, Economic Analysis of Water Use. Liège, Belgium.

Janssens, L., Stoks, R., 2014. Non-pathogenic aquatic bacteria activate the immune system and increase predation risk in damselfly larvae. Freshwater Biology 59, 417-426. https://doi.org/10.1111/fwb.12274

Joachim, S., Beaudouin, R., Daniele, G., Geffard, A., Bado-Nilles, A., Tebby, C., Palluel, O., Dedourge-Geffard, O., Fieu, M., Bonnard, M., Palos-Ladeiro, M., Turiès, C., Vulliet, E., David, V., Baudoin, P., James, A., Andres, S., Porcher, J.M., 2021. Effects of diclofenac on sentinel species and aquatic communities in semi-natural conditions. Ecotoxicology and Environmental Safety 211, 111812. https://doi.org/10.1016/j.ecoenv.2020.111812

Jubeaux, G., Simon, R., Salvador, A., Quéau, H., Chaumot, A., Geffard, O., 2012. Vitellogenin-like proteins in the freshwater amphipod Gammarus fossarum (Koch, 1835): functional characterization throughout reproductive process, potential for 
use as an indicator of oocyte quality and endocrine disruption biomarker in males. Aquat Toxicol 112-113, 72-82. https://doi.org/10.1016/j.aquatox.2012.01.011

Kakuta, I., 1997. Effect of sewage on blood parameters and the resistance against bacterial infection of goldfish,Carassius auratus. Environmental Toxicology and Water Quality 12, 43-51. https://doi.org/10.1002/(SICl) 10982256(1997)12:1<43::AID-TOX7>3.0.CO;2-8

Kelly, M.G., Whitton, B.A., 1987. Growth rate of the aquatic moss Rhynchostegium riparioidesin Northern England. Freshwater Biology 18, 461-468. https://doi.org/10.1111/j.1365-2427.1987.tb01331.x

Kerambrun, E., Ladeiro, M.P., Bigot- Clivot, A., Dedourge- Geffard, O., Dupuis, E., Villena, I., Aubert, D., Geffard, A., $2016 a$. Zebra mussel as a new tool to show evidence of freshwater contamination by waterborne Toxoplasma gondii. Journal of Applied Microbiology 120, 498-508. https://doi.org/10.1111/jam.12999

Kerambrun, E., Rioult, D., Delahaut, L., Evariste, L., Pain-Devin, S., Auffret, M., Geffard, A., David, E., 2016b. Variations in gene expression levels in four European zebra mussel, Dreissena polymorpha, populations in relation to metal bioaccumulation: A field study. Ecotoxicology and Environmental Safety 134, 53-63. https://doi.org/10.1016/j.ecoenv.2016.08.018

Lacaze, E., Devaux, A., Mons, R., Bony, S., Garric, J., Geffard, A., Geffard, O., 2011. DNA damage in caged Gammarus fossarum amphipods: A tool for freshwater genotoxicity assessment. Environmental Pollution 159, 1682-1691. https://doi.org/10.1016/j.envpol.2011.02.038

Le Guernic, A., Sanchez, W., Bado-Nilles, A., Palluel, O., Turies, C., Chadili, E., Cavalié, I., Delahaut, L., Adam-Guillermin, C., Porcher, J.-M., Geffard, A., Betoulle, S., Gagnaire, B., 2016. In situ effects of metal contamination from former uranium mining sites on the health of the three-spined stickleback (Gasterosteus aculeatus, L.). Ecotoxicology 25, 1234-1259. https://doi.org/10.1007/s10646-016-1677-z

Leong, T.-Y., Anderson, J.M., 1984. Adaptation of the thylakoid membranes of pea chloroplasts to light intensities. I. Study on the distribution of chlorophyll-protein complexes. Photosynth Res 5, 105-115. https://doi.org/10.1007/BF00028524

Leprêtre, M., Palos-Ladeiro, M., Faugere, J., Almunia, C., Lemoine, J., Armengaud, J., Geffard, A., Salvador, A., 2020. From shotgun to targeted proteomics: rapid Scout-MRM assay development for monitoring potential immunomarkers in Dreissena polymorpha. Analytical and Bioanalytical Chemistry 412, 7333-7347. https://doi.org/10.1007/s00216-02002868-2

Ljungquist, Å., Augustinsson, K.-B., 1971. Purification and Properties of Two Carboxylesterases from Rat-Liver Microsomes. European Journal of Biochemistry 23, 303-313. https://doi.org/10.1111/j.1432-1033.1971.tb01622.x

Lopes, C., Chaumot, A., Xuereb, B., Coulaud, R., Jubeaux, G., Quéau, H., François, A., Geffard, O., 2020. In Situ Reproductive Bioassay with Caged Gammarus fossarum (Crustacea): Part 2-Evaluating the Relevance of Using a Molt Cycle Temperature-Dependent Model as a Reference to Assess Toxicity in Freshwater Monitoring. Environ Toxicol Chem 39, 678-691. https://doi.org/10.1002/etc.4656

Louis, F., Rocher, B., Barjhoux, I., Bultelle, F., Dedourge-Geffard, O., Gaillet, V., Bonnard, I., Delahaut, L., Pain-Devin, S., Geffard, A., Paris-Palacios, S., David, E., 2020. Seasonal monitoring of cellular energy metabolism in a sentinel species, Dreissena polymorpha (bivalve): Effect of global change? Science of The Total Environment 725, 138450. https://doi.org/10.1016/j.scitotenv.2020.138450

Mackinney, G., 1941. Absorption of light by chlorophyll solutions. Journal of Biological Chemistry 140, 315-322. https://doi.org/10.1016/S0021-9258(18)51320-X

Macneil, C., Dick, J.T.A., Elwood, R.W., 1997. The Trophic Ecology of Freshwater Gammarus Spp. (crustacea:amphipoda): Problems and Perspectives Concerning the Functional Feeding Group Concept. Biological Reviews 72, 349-364. https://doi.org/10.1111/j.1469-185X.1997.tb00017.x

Maltby, L., Clayton, S.A., Wood, R.M., McLoughlin, N., 2002. Evaluation of the Gammarus pulex in situ feeding assay as a biomonitor of water quality: Robustness, responsiveness, and relevance. Environmental Toxicology and Chemistry 21, 361-368. https://doi.org/10.1002/etc.5620210219

Marchand, A., Tebby, C., Beaudouin, R., Hani, Y.M.I., Porcher, J.-M., Turies, C., Bado-Nilles, A., 2019. Modelling the effect of season, sex, and body size on the three-spined stickleback, Gasterosteus aculeatus, cellular innate immunomarkers: A proposition of laboratory reference ranges. Science of The Total Environment 648, 337-349. https://doi.org/10.1016/j.scitotenv.2018.07.381

Ménard, L., Escarné, R., Marcogliese, D.J., Cyr, D., Fournier, M., Gagné, F., 2010. The impacts of urban pollution on the immune system of spottail shiners. Fresenius Environmental Bulletin 19, 7.

Mersch, J., Pihan, J.-C., 1993. Simultaneous assessment of environmental impact on condition and trace metal availability in zebra mussels Dreissena polymorpha transplanted into the Wiltz River, Luxembourg. Comparison with the aquatic moss. Arch. Environ. Contam. Toxicol. 25, 353-364. https://doi.org/10.1007/BF00210727

Metcalfe, C., Hoque, M.E., Sultana, T., Murray, C., Helm, P., Kleywegt, S., 2014. Monitoring for contaminants of emerging concern in drinking water using POCIS passive samplers. Environmental Science: Processes \& Impacts 16, 473. https://doi.org/10.1039/c3em00508a

Palais, F., Dedourge-Geffard, O., Beaudon, A., Pain-Devin, S., Trapp, J., Geffard, O., Noury, P., Gourlay-Francé, C., Uher, E., Mouneyrac, C., Biagianti-Risbourg, S., Geffard, A., 2012. One-year monitoring of core biomarker and digestive enzyme responses in transplanted zebra mussels (Dreissena polymorpha). Ecotoxicology 21, 888-905. https://doi.org/10.1007/s10646-012-0851-1

Peakall, D., Walker, C., 1994. The Role of Biomarkers in Environmental Assessment .3. Vertebrates. Ecotoxicology 3, $173-179$. https://doi.org/10.1007/BF00117082 
Qiu-Fang, Z., Yuan-Yuan, L., Cai-Hong, P., Cong-Ming, L., Bao-Shan, W., 2005. NaCl enhances thylakoid-bound SOD activity in the leaves of C3 halophyte Suaeda salsa L. Plant Science 168, 423-430. https://doi.org/10.1016/j.plantsci.2004.09.002

R Development Core Team, 2014. R: A Language and Environment for Statistical Computing. R Foundation for Statistical Computing, Vienna, Austria.

Roy, S., Ihantola, R., Hänninen, O., 1992. Peroxidase activity in lake macrophytes and its relation to pollution tolerance. Environmental and Experimental Botany 32, 457-464. https://doi.org/10.1016/0098-8472(92)90058-A

Sanchez, W., Aït-Aïssa, S., Palluel, O., Ditche, J.-M., Porcher, J.-M., 2007. Preliminary investigation of multi-biomarker responses in three-spined stickleback (Gasterosteus aculeatus L.) sampled in contaminated streams. Ecotoxicology 16, 279-287. https://doi.org/10.1007/s10646-006-0131-z

Sanchez, W., Burgeot, T., Porcher, J.-M., 2013. A novel "Integrated Biomarker Response" calculation based on reference deviation concept. Environ Sci Pollut Res 20, 2721-2725. https://doi.org/10.1007/s11356-012-1359-1

Sanchez, W., Goin, C., Brion, F., Olsson, P.E., Goksøyr, A., Porcher, J.M., 2008. A new ELISA for the three-spined stickleback (Gasterosteus aculeatus L.) spiggin, using antibodies against synthetic peptide. Comparative Biochemistry and Physiology Part C: Toxicology \& Pharmacology 147, 129-137. https://doi.org/10.1016/j.cbpc.2007.08.007

Sanchez, W., Palluel, O., Meunier, L., Coquery, M., Porcher, J.-M., Aït-Aïssa, S., 2005. Copper-induced oxidative stress in three-spined stickleback: relationship with hepatic metal levels. Environ. Toxicol. Pharmacol. 19, 177-183. https://doi.org/10.1016/j.etap.2004.07.003

Siebert, A., Bruns, I., Krauss, G.-J., Miersch, J., Markert, B., 1996. The use of the aquatic moss Fontinalis antipyretica L. ex Hedw. as a bioindicator for heavy metals: 1. Fundamental investigations into heavy metal accumulation in Fontinalis antipyretica L. ex Hedw. Science of The Total Environment 177, 137-144. https://doi.org/10.1016/0048-9697(95)04891-X

Sobjak, T.M., Romão, S., do Nascimento, C.Z., dos Santos, A.F.P., Vogel, L., Guimarães, A.T.B., 2017. Assessment of the oxidative and neurotoxic effects of glyphosate pesticide on the larvae of Rhamdia quelen fish. Chemosphere 182, 267275. https://doi.org/10.1016/j.chemosphere.2017.05.031

Sossey Alaoui, K., Tychon, B., Joachim, S., Geffard, A., Nott, K., Ronkart, S., Porcher, J.-M., Beaudouin, R., Robert, C., Fauconnier, M.-L., Saive, M., 2021. Toxic effects of a mixture of five pharmaceutical drugs assessed using Fontinalis antipyretica Hedw. Ecotoxicology and Environmental Safety 225, 112727. https://doi.org/10.1016/j.ecoenv.2021.112727

Sossey-Alaoui, K., Rosillo, F., 2013. Macrophytic Distribution and Trophic State of Some Natural and Impacted Watercourses Belgium Wallonia. Int. j. water sci. 1. https://doi.org/10.5772/56609

Trapp, J., Geffard, O., Imbert, G., Gaillard, J.-C., Davin, A.-H., Chaumot, A., Armengaud, J., 2014. Proteogenomics of Gammarus fossarum to Document the Reproductive System of Amphipods *. Molecular \& Cellular Proteomics 13, 36123625. https://doi.org/10.1074/mcp.M114.038851

Verslycke, T., Vercauteren, J., Devos, C., Moens, L., Sandra, P., Janssen, C.R., 2003. Cellular energy allocation in the estuarine mysid shrimp Neomysis integer (Crustacea: Mysidacea) following tributyltin exposure. Journal of Experimental Marine Biology and Ecology 288, 167-179. https://doi.org/10.1016/S0022-0981(03)00006-6

Welton, J.S., 1979. Life-history and production of the amphipod Gammarus pulex in a Dorset chalk stream. Freshwater Biology 9, 263-275. https://doi.org/10.1111/j.1365-2427.1979.tb01508.x

Wheelock, C.E., Phillips, B.M., Anderson, B.S., Miller, J.L., Miller, M.J., Hammock, B.D., 2008. Applications of carboxylesterase activity in environmental monitoring and toxicity identification evaluations (TIEs). Rev Environ Contam Toxicol 195, 117178. https://doi.org/10.1007/978-0-387-77030-7_5

Xuereb, B., Chaumot, A., Mons, R., Garric, J., Geffard, O., 2009. Acetylcholinesterase activity in Gammarus fossarum (Crustacea Amphipoda): Intrinsic variability, reference levels, and a reliable tool for field surveys. Aquatic Toxicology 93 , 225-233. https://doi.org/10.1016/j.aquatox.2009.05.006

Yurukova, L., Gecheva, G., 2003. Active and Passive Biomonitoring using Fontinalis antipyretica in Maritsa River, Bulgaria. Journal of Balkan Ecology 6, 390-397. 